ERIA Discussion Paper Series

\title{
Toward a Single Aviation Market in ASEAN: Regulatory Reform and Industry Challenges
}

\author{
Alan Khee-Jin TAN \\ Faculty of Law, National University of Singapore
}

October 2013

\begin{abstract}
The ASEAN Single Aviation Market or Open Skies project aims to liberalize the air transport industry in ASEAN by 2015. However, the project faces significant obstacles, including non-acceptance by key member states and an incomplete agenda that excludes more ambitious relaxations to market access and ownership and control rules. The ASEAN states' failure to forge a truly single market and a common negotiating position risks disadvantaging their airlines visà-vis competitors from larger unified markets such as China.
\end{abstract}

Keywords: Air Transportation, Air Travel, Airline, Aviation

JEL classification: L93 


\section{Overview}

The ten member states of the Association of Southeast Asian Nations (ASEAN) have identified a 2015 deadline to establish an ASEAN Single Aviation Market (ASAM) for the liberalization of air transport services in the region. Also referred to as the "ASEAN Open Skies" policy, the aim is to have the ASAM in place by the time the proposed ASEAN Economic Community (AEC) takes effect in 2015.

An "open skies" proposal for the region has been discussed since the 1990s (Findlay and Forsyth, 1992). The proposal was subsequently included as an area of cooperation in the so-called "Plan of Action for Transport and Communications (1994-1996)”. At that time, a Framework Agreement on Services (FAS) had been adopted to liberalize trade in services beyond the commitments undertaken in the World Trade Organization's General Agreement on Trade in Services (GATS). Subsequently, the discussions took place in the larger context of greater economic integration across all sectors through the harmonization of trade and investment policies. To that end, air travel became one of the 12 designated priority sectors for economic integration, all of which are key components for the proposed AEC.

Over the years, the concept of progressive liberalization of air transport services has been reaffirmed at successive high-level fora, particularly at the annual ASEAN Transport Ministers’ Meetings (ATMs). In November 2004, building upon earlier discussions, the 10th ATM in Phnom Penh, Cambodia, adopted an Action Plan for ASEAN Air Transport Integration and Liberalization 2005-2015 (ASEAN, 2004). This plan established certain strategic actions to further liberalize air services and to promote an enabling environment for a single and unified air transport market in the region. This Action Plan, together with an accompanying document known as the Roadmap for Integration of Air Travel Sector (RIATS), laid down the now-familiar target date of 2015 for achieving an effective “open skies” regime for the region.

Within this broad objective, RIATS identified the following specific goals and target dates:

(i) for air freight (cargo) services, significant liberalization by 2006, and full liberalization by 2008; 
(ii) for scheduled passenger services,

- unlimited third and fourth freedom flights for all designated points within ASEAN sub-regions by 2005, and for at least two designated points in each country between the ASEAN sub-regions by 2006;

- unlimited fifth freedom traffic between designated points within the ASEAN sub-regions by 2006 and at least two designated points in each country between the ASEAN sub-regions by 2008;

- unlimited third and fourth freedom flights between the capital cities by 2008;

- $\quad$ unlimited fifth freedom flights for the capital cities by 2010.

In the meantime, several "early mover" member states had gone ahead to adopt limited agreements among themselves to relax market access restrictions. For instance, Brunei, Singapore and Thailand concluded an agreement in December 2004 that freed up access among their points. This was in line with the ASEAN 2+X principle that facilitated like-minded countries to liberalize earlier among themselves and for others to join in when ready. Farther north, Cambodia, Lao PDR, Myanmar and Vietnam also adopted a multilateral agreement in 2003 known as the CLMV Agreement (after the initials of these state parties). Several member states also liberalized on a bilateral basis. For instance, Malaysia and Singapore fully liberalized third and fourth freedom access between their respective points in December 2008 in line with and ahead of their RIATS commitments.

At this juncture, it is critical to appreciate what exactly the various "freedoms" entail. In aviation nomenclature, commercial flights by airlines are negotiated by states in the form of so-called "freedoms". To take an example, a Singapore carrier flying between Singapore and Bangkok, Thailand would require the "first freedom" to overfly Malaysian airspace and the "second freedom" to stop in Malaysia for fuel and supplies, if necessary. Both these "freedoms" are granted by Malaysia to Singapore (and reciprocally by Singapore to Malaysia for the latter's carriers) in bilateral negotiations between both governments.

The actual commercial opportunities are covered by the subsequent "freedoms". Expanding on the above example, the Singapore carrier has rights to carry 
passengers, cargo and baggage for profit from Singapore to Bangkok utilising the "third freedom" granted by Thailand to Singapore. The reverse journey back to Singapore with the same rights would constitute the "fourth freedom". In both directions, the carrier may have the right to stop over in Kuala Lumpur, Malaysia to drop off some passengers and fill up the vacated seats with new passengers picked up from there. This is the "fifth freedom" granted to Singapore by both Thailand and Malaysia, allowing Singapore carriers to carry traffic for profit between them. All these "freedoms" or rights are granted by states to each other through bilateral negotiations, often with flight and capacity limits. It is then up to the individual states to designate which of their carriers would enjoy these specific rights.

\section{MAAS, MAFLPAS and Market Access Liberalization}

At the 13th ATM held in Singapore in November 2007, the Transport Ministers reaffirmed their commitment toward the RIATS goals and agreed to expand RIATS to implement the ASEAN open skies policy by 2015 as part of the formal ASEAN Single Aviation Market (ASAM). Concurrently, the text of an ASEAN multilateral agreement for passenger services was finalized, containing draft implementing protocols formalizing the liberalized rights and deadlines first laid down by RIATS. At the same time, a draft corresponding agreement was prepared to deal with the provision of air freight (cargo) services.

Since then, the RIATS commitments for passenger services have been successfully incorporated into two formal legal agreements for ASEAN member states' acceptance. These are the Multilateral Agreement on Air Services (MAAS) and the Multilateral Agreement for Full Liberalization of Passenger Air Services (MAFLPAS), adopted in 2009 and 2010 respectively. Concurrently, an agreement for cargo transport was also adopted - the 2009 Multilateral Agreement for Full Liberalization of Air Freight Services (MAFLAFS). The MAFLAFS will be analysed at the end of this paper. For now, the focus is on the provision of passenger air services. 
The MAAS and MAFLPAS and their Implementing Protocols spell out the RIATS liberalizing targets in phased stages. To begin with, MAAS and MAFLPAS provide that each contracting state party will provide the designated airlines of the other contracting parties the right to fly across its territory without landing (the "first freedom”) and the right to make stops in its territory for non-traffic purposes (the "second freedom”).

The Implementing Protocols of MAAS then proceed to lay out the following "third", "fourth" and "fifth" freedom market access rights:

Protocol 1 - Unlimited Third and Fourth Freedom Traffic Rights Within ASEAN SubRegion

Protocol 2 - Unlimited Fifth Freedom Traffic Rights Within ASEAN Sub-Region

Protocol 3 - Unlimited Third and Fourth Freedom Traffic Rights Between ASEAN SubRegions

Protocol 4 - Unlimited Fifth Freedom Traffic Rights Between ASEAN Sub-Regions

Protocol 5 - Unlimited Third and Fourth Freedom Traffic Rights Between ASEAN Capital Cities

Protocol 6 - Unlimited Fifth Freedom Traffic Rights Between ASEAN Capital Cities

On their part, the Implementing Protocols of MAFLPAS address the following “third”, “fourth” and “fifth” freedom market access rights:

Protocol 1 - Unlimited Third and Fourth Freedom Traffic Rights Between Any ASEAN Cities

Protocol 2 - Unlimited Fifth Freedom Traffic Rights Between Any ASEAN Cities

The first four Implementing Protocols of MAAS - Protocols 1 to 4 - are limited in impact and relatively straightforward. This is because they only deal with market access relaxations designed to spur growth within sub-regions straddling the boundary regions of member states (Forsyth, et al., 2006). Four such sub-regions have so far been identified (new sub-regions may be declared or existing ones expanded): the Brunei, Indonesia, Malaysia and Philippines East ASEAN Growth Area (BIMP-EAGA), the Sub-regional Cooperation in Air Transport among Cambodia, Lao PDR, Myanmar and Vietnam (CLMV), the Indonesia, Malaysia, Singapore Growth Triangle (IMS-GT) and the Indonesia, Malaysia, Thailand Growth Triangle (IMT-GT).

The four sub-regions and their respective designated points are listed in Table 1 below, while Table 2 lists the cities designated under Protocols 5 and 6. 
Table 1: MAAS Protocols 1 to 4 and Designated Points

\begin{tabular}{|c|c|c|c|c|c|}
\hline $\begin{array}{l}\text { Sub- } \\
\text { region }\end{array}$ & $\begin{array}{l}\text { Member } \\
\text { States }\end{array}$ & $\begin{array}{l}\text { Protocol 1: } \\
\text { Third \& Fourth } \\
\text { Freedom Within } \\
\text { Sub-region }\end{array}$ & $\begin{array}{l}\text { Protocol 2: } \\
\text { Fifth Freedom } \\
\text { Within Sub-region }\end{array}$ & $\begin{array}{l}\text { Protocol 3: } \\
\text { Third \& Fourth } \\
\text { Freedom Between } \\
\text { Sub-regions }\end{array}$ & $\begin{array}{l}\text { Protocol 4: } \\
\text { Fifth Freedom } \\
\text { Between Sub-regions }\end{array}$ \\
\hline \multirow{14}{*}{$\begin{array}{l}\text { BIMP- } \\
\text { EAGA }\end{array}$} & \multirow[t]{2}{*}{ Brunei } & \multirow{2}{*}{$\begin{array}{l}\text { Bandar Seri } \\
\text { Begawan }\end{array}$} & \multirow{2}{*}{$\begin{array}{l}\text { Bandar Seri } \\
\text { Begawan }\end{array}$} & \multirow{2}{*}{$\begin{array}{l}\text { Bandar Seri } \\
\text { Begawan }\end{array}$} & Bandar Seri \\
\hline & & & & & Begawan \\
\hline & \multirow[t]{4}{*}{ Indonesia } & Balikpapan & Balikpapan & \multirow{4}{*}{$\begin{array}{l}\text { Balikpapan } \\
\text { Manado }\end{array}$} & Balikpapan \\
\hline & & Manado & Manado & & \\
\hline & & Pontianak & Pontianak & & Manađo \\
\hline & & Tarakan & Tarakan & & \\
\hline & \multirow[t]{4}{*}{ Malaysia } & Kota Kinabalu & Kota Kinabalu & \multirow{4}{*}{$\begin{array}{l}\text { Labuan } \\
\text { Miri }\end{array}$} & Labuan \\
\hline & & Labuan & Labuan & & Miri \\
\hline & & Kuching & Kuching & & IVIIII \\
\hline & & Miri & Miri & & \\
\hline & \multirow[t]{4}{*}{ Philippines } & Davao & Davao & \multirow{4}{*}{$\begin{array}{l}\text { Davao } \\
\text { General Santos } \\
\text { Puerto Princesa } \\
\text { Zamboanga } \\
\end{array}$} & Davao \\
\hline & & General Santos & General Santos & & \\
\hline & & Puerto Princesa & Puerto Princesa & & zamboanga \\
\hline & & Zamboanga & Zamboanga & & \\
\hline \multirow[t]{15}{*}{ CLMV } & Cambodia & Phnom Penh & Phnom Penh & Phnom Penh & Phnom Penh \\
\hline & \multirow[t]{4}{*}{ Lao PDR } & \multirow{4}{*}{$\begin{array}{l}\text { Vientiane } \\
\text { Luang Phabang } \\
\text { Pakse }\end{array}$} & \multirow{4}{*}{$\begin{array}{l}\text { Vientiane } \\
\text { Luang Phabang } \\
\text { Pakse }\end{array}$} & \multirow{4}{*}{$\begin{array}{l}\text { Vientiane } \\
\text { Luang Phabang } \\
\text { Pakse }\end{array}$} & Vientiane \\
\hline & & & & & Luang Phabang \\
\hline & & & & & Luang 1 mavang \\
\hline & & & & & Pakse \\
\hline & \multirow[t]{2}{*}{ Myanmar } & \multirow{2}{*}{$\begin{array}{l}\text { Yangon } \\
\text { Mandalay }\end{array}$} & \multirow{2}{*}{$\begin{array}{l}\text { Yangon } \\
\text { Mandalay }\end{array}$} & \multirow{2}{*}{$\begin{array}{l}\text { Yangon } \\
\text { Mandalay }\end{array}$} & Yangon \\
\hline & & & & & Mandalay \\
\hline & \multirow[t]{8}{*}{ Vietnam } & \multirow{8}{*}{$\begin{array}{l}\text { Ha Noi } \\
\text { Ho Chi Minh City } \\
\text { Da Nang } \\
\text { Dien Bien Phu } \\
\text { Phu Bai } \\
\text { Cat Bi } \\
\text { Lien Khuong }\end{array}$} & Ha Noi & Ha Noi & Ha Noi \\
\hline & & & Ho Chi Minh City & Da Nang & Da Nang \\
\hline & & & Da Nang & Dien Bien Phu & Dd Ivallg \\
\hline & & & Dien Bien Phu & Phu Bai & Dien Bien Phu \\
\hline & & & Phu Bai & Cat Bi & Phu Bai \\
\hline & & & Cat Bi & Lien Khuong & \\
\hline & & & Lien Khuong & & Cat Bi \\
\hline & & & & & Lien Khuong \\
\hline IMS- & Indonesia & & & & \\
\hline GT & Malaysia & NOT APPLICABLE & & & \\
\hline & Singapore & & & & \\
\hline IMT- & Indonesia & Medan & Medan & Medan & Medan \\
\hline GT & & Padang & Padang & Padang & Padang \\
\hline & & $\begin{array}{l}\text { Banda Aceh } \\
\text { Nias }\end{array}$ & $\begin{array}{l}\text { Banda Aceh } \\
\text { Nias }\end{array}$ & & \\
\hline & Malaysia & Penang & Penang & Alor Star & Alor Star \\
\hline & & Langkawi & Langkawi & Ipoh & Inoh \\
\hline & & Alor Star & Alor Star & & \\
\hline & & Ipoh & Ipoh & & \\
\hline & & Kota Bharu & Kota Bharu & & \\
\hline & Thailand & Hat Yai & Hat Yai & Hat Yai & Hat Yai \\
\hline & & Narathiwat & Narathiwat & Narathiwat & Narathiwat \\
\hline & & Pattani & Pattani & Pattani & \\
\hline & & Trang & Trang & Trang & Pattani \\
\hline & & Nakon Si & Nakon Si & Nakon Si & Trang \\
\hline & & Thammarat & Thammarat & Thammarat & IIdilg \\
\hline & & & & & Nakon Si \\
\hline & & & & & Thammarat \\
\hline
\end{tabular}

Source: MAAS Implementing Protocols 1 to 4. 
Table 2: MAAS Protocols 5 and 6 and Designated Capital Cities

\begin{tabular}{lll}
\hline Member States & $\begin{array}{l}\text { Protocol 5: Third \& Fourth } \\
\text { Freedom }\end{array}$ & $\begin{array}{l}\text { Protocol 6: Fifth Freedom } \\
\text { Between ASEAN Capital Cities }\end{array}$ \\
& Between ASEAN Capital Cities & \\
\hline \hline Brunei & Bandar Seri Begawan & \\
Cambodia & Phnom Penh & \\
Indonesia & Jakarta & \\
Lao PDR & Vientiane & \\
Malaysia & Kuala Lumpur & \\
Myanmar & Yangon & \\
Philippines & Manila & \\
Singapore & Singapore & \\
Thailand & Bangkok & \\
Vietnam & Ha Noi & \\
\hline
\end{tabular}

Source: MAAS Implementing Protocols 5 and 6.

The idea of relaxing market access rights within and between sub-regions demonstrates ASEAN's incrementalist philosophy of starting with modest goals first and pursuing more ambitious relaxations at a later stage. As noted above, RIATS had earlier laid down specific deadlines for achieving the sub-regional relaxations. MAAS Protocols 1 to 4 reaffirm these substantive commitments. It should be noted, though, that by the time MAAS and its Implementing Protocols were adopted in May 2009, the deadlines first identified by RIATS had all expired (with the exception of unlimited fifth freedom for capital cities slated for 2010). There was thus a delay in formalizing the RIATS commitments into binding legal agreements.

In any event, MAAS Protocol 1 provides that designated airlines from each contracting party shall be allowed to operate unlimited third and fourth freedom passenger services from any designated points in its territory to any designated points in the sub-region to which it belongs. The Protocol lists the designated cities by country - for the BIMP-EAGA sub-region, for instance, Bandar Sri Begawan is designated by Brunei; Balikpapan, Manado, Tarakan and Pontianak by Indonesia; Kota Kinabalu, Labuan, Miri and Kuching by Malaysia; and Davao, Puerto Princesa, Zamboanga and General Santos by the Philippines. 
Pursuant to Protocol 1, a Malaysian carrier, for instance, will thus be allowed to mount unlimited third and fourth freedom operations between its home points and another foreign point in the same sub-region (e.g. Kuching - Davao and Miri Balikpapan). Of course, this assumes that Malaysia, the Philippines and Indonesia are state parties to Protocol 1, which is the case. Similarly, Protocol 2 allows unlimited fifth freedom operations involving the same designated points within the relevant sub-region. Hence, a Malaysian carrier can depart from Kuching, make a stopover in Bandar Seri Begawan, Brunei to discharge and pick up traffic, and continue to Davao in the Philippines.

On their part, Protocols 3 and 4 provide for third/fourth and fifth freedom rights respectively between the various sub-regions. As such, the degree of liberalization is higher and more ambitious, taking in points across sub-regions. Notably, however, the list of designated cities for the exercise of these rights becomes whittled down. This is due to the various states seeking to protect their own carriers' operations and becoming more cautious toward granting greater access for other states' carriers. Hence, Indonesia has designated only Balikpapan and Manado for the BIMP-EAGA sub-region and Medan and Padang for the IMT-GT sub-region.

For its part, Malaysia has designated only Labuan and Miri for BIMP-EAGA (omitting the two larger cities, Kuching and Kota Kinabalu) and only Alor Star and Ipoh for IMT-GT (omitting Penang). Unlimited operations under Protocol 3 would thus be possible for Malaysian carriers between, say, Miri (in BIMP-EAGA) and Medan, Indonesia (in IMT-GT). For Protocol 4 "fifth freedom" operations, the Malaysian carrier can operate across sub-regions by connecting, for instance, Ipoh, Davao and Phnom Penh and vice-versa, with pick-up rights in Davao.

What is obvious is that the designated points in the sub-regions covered by Protocols 1 to 4 are mainly secondary cities. In terms of air traffic volume and market potential, Protocols 5 and 6 have much greater economic impact as these cover the ten capital cities and are not bound by sub-regional proximity. Specifically, Protocol 5 provides contracting states' designated carriers with unlimited third and fourth freedom opportunities between their own capital city and all other ASEAN capital cities. Protocol 5 further provides that such rights shall be allowed by 31 December 2008 (although, as noted above, the Protocol was only 
adopted in May 2009). On its part, Protocol 6 lays down a deadline of 31 December 2010 for a contracting state's designated carriers to operate full third, fourth and fifth freedom rights from their capital city to other contracting states’ capital cities.

As for the subsequent MAFLPAS agreement that was adopted in 2010, this was designed to supplement MAAS and to "mop up" the rest of the ASEAN cities. Hence, MAFLPAS Protocol 1 allows for unlimited third and fourth freedom operations for carriers of state parties between any two non-capital cities, or between a non-capital and a capital city (capital-to-capital operations remain governed by MAAS Protocol 5). Like the corresponding MAAS operations, by virtue of the definition of third and fourth freedom rights, the flight must begin and end in the territory of the carrier's home state. Examples of operations under MAFLPAS Protocol 1 include a Thai carrier operating between Bangkok and Bali, Phuket and Bali, and Phuket and Jakarta.

On its part, MAFLPAS Protocol 2 provides for unlimited fifth freedom operations among non-capital cities. On its terms, Protocol 2 can also cover flights involving capital cities, except when all three points are capitals in which case MAAS Protocol 6 governs. Hence, MAFLPAS Protocol 2 covers the following examples of a Thai carrier's fifth freedom operations from Thailand to the Philippines via Vietnam (note: “c”” denotes capital while “nc” denotes non-capital):

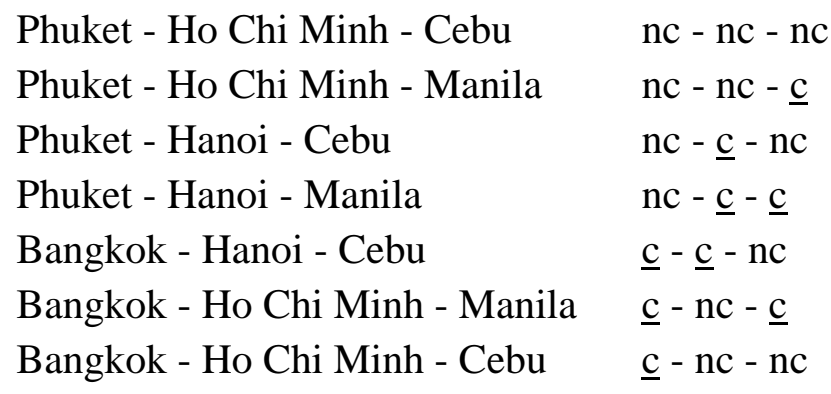

\section{State Parties to the MAAS, MAFLPAS and Implementing Protocols}

The critical point to be addressed next is the ratification record of ASEAN member states for the above instruments. It must be remembered that the MAAS and MAFLPAS Implementing Protocols that spell out the above market access 
"freedoms" are legal instruments that stand separately from their "parent” MAAS and MAFLPAS agreements. Hence, these Protocols must be individually accepted by member states before they can take effect for those states.

Obviously, if all 10 ASEAN member states accept and become contracting parties to the MAAS and MAFLPAS agreements and all their Implementing Protocols, an unlimited third, fourth and fifth freedom regime between and among all international points in ASEAN will be in full and immediate effect. However, that is not currently the case, as shall be assessed below.

The following tables provide the ratification record of the ASEAN member states for MAAS and MAFLPAS and their respective Implementing Protocols as at July 2013:

Table 3: Ratification Status of 2009 Multilateral Agreement on Air Services (MAAS)

\begin{tabular}{|c|c|c|c|c|c|c|c|}
\hline & $\begin{array}{l}\text { MAAS } \\
\text { (Parent } \\
\text { Agreement) }\end{array}$ & $\begin{array}{l}\text { Protocol } \\
\text { 1: third } \\
\& \text { fourth } \\
\text { freedom } \\
\text { within } \\
\text { sub- } \\
\text { region }\end{array}$ & $\begin{array}{l}\text { Protocol } \\
\text { 2: fifth } \\
\text { freedom } \\
\text { within } \\
\text { sub- } \\
\text { region }\end{array}$ & $\begin{array}{l}\text { Protocol } \\
\text { 3: third } \\
\text { \& fourth } \\
\text { freedom } \\
\text { between } \\
\text { sub- } \\
\text { regions }\end{array}$ & $\begin{array}{l}\text { Protocol } \\
\text { 4: fifth } \\
\text { freedom } \\
\text { between } \\
\text { sub- } \\
\text { regions }\end{array}$ & $\begin{array}{l}\text { Protocol } \\
\text { 5: } \\
\text { third \& } \\
\text { fourth } \\
\text { freedom } \\
\text { between } \\
\text { capitals }\end{array}$ & $\begin{array}{l}\text { Protocol } \\
\text { 6: fifth } \\
\text { freedom } \\
\text { between } \\
\text { capitals }\end{array}$ \\
\hline Brunei & $\bar{v}$ & $\bar{q}$ & $\bar{q}$ & $\bar{q}$ & $\bar{v}$ & $\bar{v}$ & $\bar{q}$ \\
\hline Cambodia & $\checkmark$ & $\checkmark$ & $\checkmark$ & $\checkmark$ & $\checkmark$ & $\checkmark$ & $\checkmark$ \\
\hline Indonesia & $\checkmark$ & $\checkmark$ & $\checkmark$ & $\checkmark$ & $\checkmark$ & {$[\mathrm{X}]$} & {$[\mathrm{X}]$} \\
\hline Lao PDR & $\checkmark$ & $\checkmark$ & $\checkmark$ & $\checkmark$ & $\checkmark$ & $\checkmark$ & $\checkmark$ \\
\hline Malaysia & $\checkmark$ & $\checkmark$ & $\checkmark$ & $\checkmark$ & $\checkmark$ & $\checkmark$ & $\checkmark$ \\
\hline Myanmar & $\checkmark$ & $\checkmark$ & $\checkmark$ & $\checkmark$ & $\checkmark$ & $\checkmark$ & $\checkmark$ \\
\hline Philippines & $\checkmark$ & $\checkmark$ & $\checkmark$ & $\checkmark$ & $\checkmark$ & {$[\mathrm{X}]$} & {$[\mathrm{X}]$} \\
\hline Singapore & $\checkmark$ & $\checkmark$ & $\checkmark$ & $\checkmark$ & $\checkmark$ & $\checkmark$ & $\checkmark$ \\
\hline Thailand & $\checkmark$ & $\checkmark$ & $\checkmark$ & $\checkmark$ & $\checkmark$ & $\checkmark$ & $\checkmark$ \\
\hline Vietnam & $\checkmark$ & $\checkmark$ & $\checkmark$ & $\checkmark$ & $\checkmark$ & $\checkmark$ & $\checkmark$ \\
\hline
\end{tabular}

Source: ASEAN Secretariat. $\checkmark$ denotes state party, [ X ] denotes non-state party 
Table 4: Ratification Status of 2010 Multilateral Agreement for Full Liberalization of Passenger Air Services (MAFLPAS)

\begin{tabular}{lcccc}
\hline & $\begin{array}{c}\text { MAFLPAS } \\
\text { (Parent Agreement) }\end{array}$ & $\begin{array}{c}\text { Protocol 1: third \& } \\
\text { fourth freedom between } \\
\text { cities }\end{array}$ & $\begin{array}{c}\text { Protocol } \\
\text { freedom between cities }\end{array}$ \\
\hline Brunei & $\checkmark$ & $\checkmark$ & $\checkmark$ \\
Cambodia & {$[$ X ] } & {$[$ X ] } & [ X ] \\
Indonesia & {$[$ X ] } & {$[$ X ] } & [ X ] \\
Lao PDR & {$[$ X ] } & {$[$ X ] } & $\checkmark$ \\
Malaysia & $\checkmark$ & $\checkmark$ & $\checkmark$ \\
Myanmar & $\checkmark$ & $\checkmark$ & $\checkmark$ \\
Philippines & $\checkmark$ & $\checkmark$ & $\checkmark$ \\
Singapore & $\checkmark$ & $\checkmark$ & $\checkmark$ \\
Thailand & $\checkmark$ & $\checkmark$ & $\checkmark$ \\
Vietnam & $\checkmark$ & $\checkmark$ & \\
\hline Source: ASEAN Secretariat. $\checkmark$ denotes state party, [ X ] denotes non-state party &
\end{tabular}

Both MAAS and MAFLPAS have now entered into force after receiving the acceptance of the minimum number of three member states for each agreement. At the same time, each of the respective Implementing Protocols has separate requirements for entry into force. These have also been satisfied, and all the Protocols are now in force for those states that have ratified them. What is important is that the instruments only have binding effect for and among those states that have expressly accepted them. As shown in Table 3, the states that have notably not accepted MAAS Protocols 5 and 6 are Indonesia and the Philippines, while Protocols 1 to 4 have been accepted by all ten states. In the case of MAFLPAS and its Protocols 1 and 2, Cambodia, Indonesia and Lao PDR have not become state parties.

The individual states' motivations require elaboration. Indonesia's position can be traced to its leading carriers' active lobbying of their government to continue protecting their international operations against those of rival airlines from neighbouring ASEAN states. Of course, it is obvious that Indonesia is the one member state whose acceptance of the ASEAN instruments is critical for the entire ASAM project. Spanning 17,000 islands and home to 270 million people 
(effectively half of the entire ASEAN population), Indonesia has the region's largest economy, population and air travel market. Its capital, Jakarta, is ASEAN's biggest city by population and also the headquarters of the ASEAN Secretariat.

However, the Indonesian airline industry, through the Indonesian National Air Carriers Association (INACA), consistently opposes efforts to open up the ASEAN air travel market. The Indonesian carriers' concern lies with their stronger competitors in the other ASEAN states, principally Singapore, Malaysia and Thailand, whom they fear will dominate the international market between Indonesia and these countries (IndII, 2012). To begin with, the Indonesian position is that as a huge archipelago, it has potentially hundreds of points to offer international aviation, whereas the other states (particularly Singapore) have all of one point to offer. This, as perceived by the Indonesian carriers such as Garuda and Lion Air, represents a systemic imbalance for exchanging traffic rights.

Such dynamics have also led the Indonesian government to propose only five points for an “open skies” policy - the major cities of Jakarta, Surabaya, Medan, Makassar and Bali. At the same time, there have been calls by INACA to implement a selective or "partial” open skies policy with some ASEAN neighbours, even if full “open skies” can be implemented with others. This suggests that access into the five cities can be fully or partially open, depending on where the foreign carrier is from. Naturally, such a "pick and choose" policy is inconsistent with the ASEAN multilateral agreements and the overall integration aims of ASAM.

The offer of the five major cities for liberalization is, in itself, to be welcomed. Even if falling short of full relaxations, it will effectively open up a sizeable amount of the international market into and out of Indonesia, given that the five cities (particularly the capital, Jakarta) account for the bulk of international traffic into the country. At the same time, there has been no indication from Indonesia that it will accept MAAS Protocol 5 that provides for unlimited third and fourth freedom capacity between capital cities.

The reality is that some airline quarters in Indonesia remain resistant to offering full and unlimited access into Jakarta, especially for Singapore, Malaysian and Thai carriers. This is consistent with the "partial” or selective open skies policy advocated by INACA. In large part, the concern revolves around the "sixth freedom" 
operations of foreign airlines, particularly those from Singapore and Malaysia. The "sixth freedom" is actually a simple combination of a "fourth freedom" (e.g. a Singapore carrier's Jakarta-Singapore operation) with a connecting "third freedom" operation (from Singapore to anywhere else). This is the familiar operating model of major "sixth freedom" carriers worldwide such as Singapore Airlines, Emirates, KLM, Korean Air, Turkish Airlines and Qatar Airways. In essence, "sixth freedom" hub operations depend simply on two factors - a geographically strategic "hub" airport in the centre of airline routes to serve as a transit stop, and unlimited third/fourth freedom rights to operate numerous "spokes" (hence, the alternative nomenclature of "hub-and-spokes" to describe the "sixth freedom").

Due to the Indonesian carriers' relatively limited international operations, most travellers from Europe, North America and Northeast Asia travel into and out of Indonesia on foreign carriers' sixth freedom operations. The largest operator in this regard is Singapore Airlines, which channels these travellers through its hub, Singapore Changi Airport. In recent years, the highly successful Malaysian low-cost carrier AirAsia has also begun to transport the budget-minded segment of travellers in this same manner through its hub at Kuala Lumpur International Airport. The discomfort with such sixth freedom operations accounts for Indonesia's reluctance to accept the ASEAN agreements, particularly MAAS Protocol 5 that opens up unlimited third and fourth freedom access into and out of Jakarta. Since third and fourth freedom flights form the backbone of sixth freedom operations, staying out of MAAS Protocol 5 is a strategy to restrict rival carriers' sixth freedom operations into and out of Jakarta.

For the Indonesian carriers, Jakarta itself is too big a prize to give up even if it constitutes only one point in the sprawling archipelago. Indeed, Jakarta accounts for the bulk of the Indonesian economy and is the principal gateway into the country. Opening up other points would also allow foreign carriers to bypass the main hubs such as Jakarta and to carry unlimited traffic directly into secondary points such as Bali, Surabaya, Medan and Lombok. This will affect the domestic business of Garuda and other local airlines that thrive on domestic connecting traffic. This explains their resistance MAFLPAS, the agreement that opens up the secondary cities. 
In short, to protect themselves from foreign competition, Garuda and the other Indonesian carriers continue to lobby their government aggressively to steer clear of the ASEAN multilateral agreements. This has the effect of restricting the other ASEAN carriers' operations into Indonesia, subjecting them to finite capacity that remains negotiated bilaterally. With Indonesia being home to half the entire ASEAN population, its decision to stay out of the ASEAN agreements hampers the ASAM project significantly. In the process, the travelling public is denied benefits such as increased competition and lower fares, and Indonesia's connectivity to the region and the outside world remains relatively poor.

The lobbying influence of the airlines must, however, be contrasted with the position of other stakeholders in the Indonesian economy. As might be expected, sectors such as the tourism industry greatly welcome the economic advantages that liberalization might bring. Indeed, the benefits of air services liberalization for the overall Indonesian economy are obvious - greater choice and lower fares for the travelling public, increased business and tourist arrivals, and positive overall effects for export-oriented businesses, inward foreign investment, airport and ancillary services and indeed, the entire economy.

In recent years, several provincial governments have emerged as keen lobbyists to champions direct flights by foreign airlines into their cities. These provincial authorities recognize that tourism and foreign investment could grow faster if there were greater direct connectivity to key regional cities. Recent economic studies commissioned by the Indonesian central government have also identified benefits of around 6 trillion Rupiah (US\$650 million) in additional GDP that could potentially accrue to the overall economy if an “open skies” policy were adopted by 2025 (IndII, 2012). As such, the aero-political landscape in Indonesia is highly complex: it would be inaccurate to assume that efforts to liberalize the air transport industry are resisted by all the major stakeholders in Indonesia.

For now, though, the airline industry clearly has the upper hand in lobbying the government to continue protecting its interests. Hence, Indonesia remains opposed to ratifying MAAS Protocols 5 and 6 and MAFLPAS Protocols 1 and 2. As a result, efforts to relax market access into Indonesia have had to be dealt with in a strictly bilateral manner. For instance, up till early 2013, Singapore carriers' capacity 
entitlement between Singapore and Indonesia (especially Jakarta) had come close to being exhausted. In January 2013, both sides agreed to increase capacity on the main routes between Singapore and Jakarta as well as Surabaya, Bali and Medan. The Indonesian government had agreed to such reciprocal but incremental additions only after capacity on the Indonesian side had itself come close to being reached. This followed the requests of several Indonesian carriers, particularly low-cost operators such as Lion Air and Indonesia AirAsia, to expand operations into Singapore. In turn, the reciprocal adjustments have allowed Singapore Airlines and Singaporebased low-cost carriers such as Tiger Airways and Jetstar Asia to increase their operations to Indonesia, including Jakarta. However, the overall capacity remains finite, strictly governed by the bilateral agreement between both sides.

In comparison, the Philippine government has a slightly different perspective. The Philippines has accepted the MAFLPAS to open up access to its secondary cities while keeping Manila restricted. This explains its staying out of MAAS Protocols 5 and 6, even while embracing MAFLPAS. The Philippines has justified its decision by reference to the shortage of landing and take-off slots and overall runway congestion at central Manila's Ninoy Aquino International Airport. In this regard, the Philippine government's preference is to liberalize access into the alternative airport at Clark, some $80 \mathrm{~km}$ northwest of downtown Manila. Indeed, access into Clark has been fully open to carriers from other ASEAN countries for some years.

While the Philippine government's concern over congestion at Ninoy Aquino International is understandable, there is much force in the argument that traffic rights and airport slots are separate matters. As such, the lack of slots at an airport should not prevent member states from ratifying the ASEAN agreements to liberalize market access rights and to signal support for ASEAN's market integration commitments. Linking slots to access rights is also a negative precedent in that it encourages governments to use congestion and lack of slots as excuses to delay their adherence to regional commitments. 


\section{Seventh Freedom and Domestic Operations: An Incomplete ASAM}

If the relatively modest third/fourth and fifth freedom relaxations analyzed above do not even enjoy full acceptance from all ASEAN member states, prospects are even bleaker for any future relaxation to "seventh freedom" and cabotage restrictions. The seventh freedom refers to the right of a carrier to connect two international points outside of its home country. A true single or common aviation market such as that which exists in Europe liberalizes such operations fully and opens the door for greater market competition throughout the region. For instance, British Airways can base a stand-alone plane or fleet to operate between Paris and Frankfurt if it wants to, without the flight having to begin or end in the U.K. (unlike fifth freedom flights which have to). The fact that British Airways has not done so is because the Paris-Frankfurt market is too competitive, and not because governments prohibit that operation. Hence, the aim is to let the market, not governments, act as a control.

With ASEAN, however, the MAAS and MAFLPAS multilateral agreements do not even address seventh freedom operations since the member states have not achieved consensus on the issue. In fact, the seventh freedom is not even on the negotiating table as a future agenda item. Similarly, the ASEAN agreements do not free up domestic or "cabotage" operations. These are also known in the industry as the "eighth freedom" (if the flight originates in the carrier's home country, e.g. a Singapore carrier operating Singapore-Jakarta-Bali) and the "ninth freedom" (the same carrier operating between Jakarta and Bali without starting or ending in Singapore). In the E.U., any E.U. carrier can now operate what were previously considered "cabotage" flights - e.g. British Airways between Frankfurt and Berlin, both points within Germany, if it wishes to.

Domestic carriage or "cabotage” remains highly sensitive for large countries with a huge domestic base. Typically, such operations are reserved exclusively for local players. In ASEAN countries, no foreign airline - not even from friendly fellow ASEAN states - can perform domestic flights, and most governments prefer to uphold that status quo. The ASAM objectives are thus modest - market access 
relaxations stop simply at the third, fourth and fifth freedoms, and do not extend to the seventh, eighth and ninth freedoms (the latter two involving domestic carriage). Consequently, AirAsia (a Malaysian carrier) cannot base a fleet in Singapore to ply routes between Singapore and third countries as these would be seventh freedom operations that compete head-on with the Singapore carriers. Neither can AirAsia operate between two domestic points in Indonesia.

How does this explain AirAsia's well-known operations in Thailand, Indonesia and the Philippines that allow it to operate from and within these countries? What happens in reality is that AirAsia has incorporated subsidiaries in those countries that are technically local airlines. Each subsidiary carries a different airline code and is (at least on paper) majority-owned and effectively controlled by local interests. Thus, AirAsia owns only minority stakes (less than 50\%) in each of these entities. The result is that AirAsia Thailand flies between Bangkok and Singapore as a Thai carrier, exercising simple third/fourth freedom rights belonging to Thailand, and not as a Malaysian carrier (if it were, it would be operating a seventh freedom flight!).

This operating model is one effective method that industry players use to get around governmental prohibitions. In effect, it allows the AirAsia group to circumvent the seventh freedom prohibition (such rights are not allowed under bilateral or multilateral agreements) and to effectively operate such flights out of their Bangkok, Jakarta and Manila hubs under a well-known common brand. For the travelling public that does not appreciate legal distinctions, all the AirAsia subsidiaries' flights are run by a single airline company, particularly since ticket sales are conducted through a common and integrated internet platform. In addition, this operating model allows circumvention of domestic "cabotage” prohibitions as well, since AirAsia Indonesia would be entirely within its right to operate domestic flights from Jakarta to Bali simply because it is an Indonesian carrier.

\section{Ownership and Control Restrictions}

The above "circumventions" remain, of course, inconvenient and less than ideal. This is because the AirAsia group has to resort to establishing overseas subsidiaries 
(and accepting only a minority shareholding in each of these) instead of operating in its own right. In other words, the vehicle of setting up subsidiaries with minority shareholding is an imperfect "stop-gap" measure that awaits further liberalization of market access rules to allow full seventh freedom and domestic operations for foreign carriers.

In this regard, market access issues are closely related to ownership and control restrictions. On top of prohibiting seventh freedom and domestic operations by foreign carriers, the current regime also disallows a carrier like AirAsia from going into, say, Indonesia, either to establish a wholly-owned subsidiary or to buy over an existing local airline fully. In comparison, these moves are permitted in the E.U. common aviation market: any E.U. national can move into another E.U. country and establish a fully-owned airline there, and fly it between any two points within the E.U. In essence, both market access and ownership and control are freed up, forming the hallmarks of a true single or common aviation market.

Within ASEAN, however, ownership and control remain highly restricted, just like market access. In most of the bilateral air services agreements between the individual ASEAN states, it is a common condition that carriers designated by the respective governments to enjoy the relevant third, fourth and fifth freedom market access rights must be "substantially owned and effectively controlled" by the designating state and/or its nationals. This means that foreign interests' stakes in a local carrier cannot exceed $49 \%$ of shareholding. In some states like the Philippines, the foreign ownership component is even stricter - no foreign interest can own more than $40 \%$ of shareholding in a Philippine carrier due to the Constitution's regard for airlines as strategic public utilities.

As explained above, the likes of AirAsia have sought to get around such restrictions by establishing local subsidiaries that are technically separate from the parent carrier. Thus, airlines like Jetstar Asia (Singapore), Jetstar Pacific (Vietnam), Tiger Mandala (Indonesia) and Malindo (Malaysia) are all majority-owned by their respective local owners with the parent airline group owning only a minority stake. In this sense, they have all scrupulously copied the original AirAsia model and are wholly faithful to the requirement of majority local ownership. These carriers also 
utilize the operating rights found in the relevant home country's bilateral agreements with other countries.

That said, the requirement of "effective control" is less clear. On the one hand, the CEOs of these subsidiary carriers are typically individuals with local nationality, and their respective boards have majority local representation (Tan, 2009). Yet, there is little doubt that managing expertise and strategic decisions do emanate from the parent foreign airline that is the minority owner, particularly because the local majority shareholders typically have no aviation experience. In terms of branding, these overseas subsidiaries share the same logo and marketing identity as their parent carriers'. For instance, the entities in the AirAsia group are effectively marketed to the traveling public as a single airline through advertisements and on a common internet booking platform. As explained earlier, this effectively gives the parent airlines multiple hubs in other countries and allows them to operate what would otherwise be prohibited seventh freedom rights. The only drawback is that the parent airlines have to accept minority ownership in the subsidiaries.

How have the two ASEAN multilateral agreements sought to deal with these ownership and control restrictions? Interestingly, both MAAS and MAFLPAS provide alternatives to the traditional "substantial ownership and effective control" rule. Specifically, they provide that contracting state parties have the right to designate an unlimited number of carriers to enjoy the relevant rights, provided that they fulfill the following criteria on ownership and control:

(a) substantial ownership and effective control of the airlines are vested in the designating state, its nationals or both (see Article 3(2)(a)(i) of MAAS); or

(b) subject to the acceptance of the contracting party receiving the application of a designated airline, the airline is incorporated in and has its principal place of business in the designating state, and is (and remains) substantially owned and effectively controlled by one or more member state and/or its nationals, and the designating state has and maintains effective regulatory control ( see Article 3(2)(a)(ii) of MAAS); or

(c) subject to the acceptance of the contracting party receiving the application of a designated airline, the airline is incorporated in and has its principal place of business in the designating state, and the designating state has and maintains effective regulatory control of that airline, provided that such arrangements will not be equivalent to allowing airline(s) or its subsidiaries access to traffic rights not otherwise available to that airline(s) (see Article 3(2)(a)(iii) of MAAS). 
The first alternative (Article 3(2)(a)(i)) is the traditional "substantial ownership and effective control" formula that adds nothing new to the existing bilateral requirements. The second (Article 3(2)(a)(ii)) is premised upon an increasingly favoured clause in more progressive bilateral air services agreements worldwide. This provides for a designated carrier to be incorporated in the designating state and to have its principal place of business in that state. Hence, in terms of shareholding, it would not matter if that carrier is owned in the majority by interests outside the designating state, as long as the seat of incorporation and principal place of doing business remain in the designating state. Such a formulation opens the door for a carrier to attract foreign capital injections beyond the customary $49 \%$ limit, and is designed to make local carriers more attractive to foreign investment.

However, the precise formulation in Article 3(2)(a)(ii) is actually more nuanced and maintains a conservative flavour. It retains the substantial ownership and effective control requirement, but provides that this can be met by "one or more member state and/or its nationals”. This lays the ground for what can be termed an “ASEAN community carrier”, whereby an airline can be substantially owned and effectively controlled by ASEAN interests, taken cumulatively or in the aggregate (Tan, 2009). For example, a carrier registered in and designated by Myanmar could have $20 \%$ of its shares owned by Singapore interests, $20 \%$ by Thai interests, $11 \%$ by local Myanmar interests, with the remaining shares owned by investors of any nationality whatsoever (including non-ASEAN). This carrier can thus be recognized for the purpose of the ASEAN agreements if it is incorporated in and has its principal place of business in Myanmar and is also effectively controlled by the ASEAN interests in the aggregate. In addition, it must explicitly come under the effective regulatory control of the Myanmar aeronautical authorities for safety, security and other regulatory matters.

The concept in Article 3(2)(a)(ii) thus distinguishes between "effective economic control" and "effective regulatory control”. While the latter must remain solely with the designating state to ensure optimal compliance with safety, security and other important regulatory matters, effective economic control (along with substantial ownership) may reside with non-nationals. What the ASEAN agreements have done is to allow substantial ownership and effective economic control to reside in the 
region with one or more member state and/or its nationals. This takes the process of liberalization one step forward, in that it allows for community ownership and control. Hence, majority ownership and effective economic control can lie with interests outside the designating state, as long as these interests are still from within the ASEAN grouping/family.

What is problematic, though, is the qualification in the agreements that the contracting party receiving the application of such a designated carrier must approve before the carrier can operate to that party (i.e. to exercise market access rights). This means that a carrier constituted according to the above trans-ASEAN ownership and control model does not possess the certainty that it can access all countries in the region. This will be a great disincentive for any airline or investor thinking of constituting an airline as such, unless a number of ASEAN member states with major markets first declare their unequivocal approval for such a model.

The ASEAN agreements should preferably have provided for member states to opt out of such a model for their own carriers, without affecting carriers from other ASEAN member states that wish to adopt the community model. However, this appears not to have been acceptable to a number of member states that still want a say or veto over the ownership structure of foreign airlines flying into their points. For now, any airline or investor who wishes to have certainty would be wise to comply with the traditional substantial ownership and effective control rule. In practice, this negates the liberalizing intent of the ASEAN agreements.

Going forward, this will be a major issue for the impending ASAM arrangement to resolve, quite apart from the market access issue analyzed earlier. The member states should work toward a regime that allows for carriers bearing a trans-ASEAN ownership structure to be recognized automatically, instead of at the discretion of each individual member state. As noted above, member states can always retain the traditional national ownership and control restrictions for their own designated carriers. This aspect of sovereignty will thus not be compromised.

As mentioned earlier, there are ASEAN states like the Philippines whose domestic laws prevent airline companies from being owned beyond a certain proportion by foreign interests ( $40 \%$ in this case). For such states, an "opt-out" clause applicable to their own carriers would suffice to ensure compliance with 
domestic laws, while allowing for fellow ASEAN states' airlines to be set up as “community carriers” (CAPA Consulting, 2008). Another possible compromise could be to allow majority ownership to be constituted in a trans-ASEAN manner, but to retain effective economic control strictly with the nationals of the designating state. This will provide the assurance of close and continuing economic links between the carrier and its designating state.

On its part, the third alternative formulation in MAAS Article 3(2)(a)(iii) envisages that a carrier need not even have substantial ownership and effective economic control reposed within the region (nor by implication, its designating state), as long as it is incorporated in and has its principal place of business in the designating state. That state must also have and maintain effective regulatory control over the airline. Hence, this is the most progressive of the three alternative options. It opens up the intriguing possibility that an airline in ASEAN could be owned and economically controlled by interests from outside the region.

However, this possibility comes with two major qualifications. One is the requirement that each contracting party receiving the airline's application must approve its operations. The shortcomings of such a discretionary requirement have been noted above. The other condition relates to the requirement that the arrangement will not be equivalent to allowing airlines or its subsidiaries access to traffic rights not otherwise available to them. This appears to reflect a concern that foreign airlines from outside the region must not be allowed to buy into an ASEAN carrier and begin using it to access intra-ASEAN routes for which they (the foreign airlines) have no underlying rights. In effect, Article 3(2)(a)(iii) will largely end up facilitating investment by foreign non-airline interests only.

\section{An Emerging "Threat": The New ASEAN-China Air Transport Agreement}

For now, MAAS and MAFLPAS are the "high points" of air services liberalization in ASEAN. If and when accepted by all ten member states, both agreements will effectively usher in fully unlimited third, fourth and fifth freedom 
operations for all ASEAN carriers from their home points to all international points in the region. In reality, however, Indonesia's participation is not certain to happen. At the same time, the liberalization of seventh freedom and domestic/cabotage operations has not even been contemplated yet, let alone the relaxation of ownership and control rules. Without seventh freedom relaxations, any international operation within ASEAN would still have to begin from and end in the carrier's home points. In addition, the incomplete relaxation of ownership and control rules (see above discussion) means that ASEAN carriers will, in effect, still need to be owned and controlled by interests in their home states.

The "single" aviation market envisaged by the two agreements is thus an unfinished piece of work and at risk of being "single" only in name. In the long term, this shortcoming will potentially create barriers for ASEAN airlines' competitiveness vis-à-vis airlines from outside the region. In particular, the ramifications of failing to forge full intra-ASEAN liberalization become evident when ASEAN, as a group, enters into deals with countries outside the group. One clear example of this is the landmark ASEAN-China Air Transport Agreement (ATA) adopted in 2010 between the ASEAN states, on the one hand, and China, on the other. In essence, the problem is that the ATA was concluded with China before the ASEAN states achieved internal liberalization of its air services market.

In substance, the ATA and its Protocol 1 provide for unlimited third and fourth freedom access for airlines on both sides, effectively superseding the relevant bilateral agreements that exist between the individual ASEAN state parties and China. Hence, all airlines from the ASEAN state parties - currently Singapore, Malaysia, Thailand, Myanmar and Vietnam - now have unlimited third and fourth freedom access and capacity into points in China, with the exception of Hong Kong, Macao and Taiwan (these were points excluded by the Chinese side). Reciprocally, the Chinese airlines have similar unlimited third and fourth freedom access between China and points in the relevant ASEAN countries that have become parties to the ATA and Protocol 1. 
Table 5: Ratification Status of 2010 ASEAN-China Air Transport Agreement (ATA)

\begin{tabular}{lccc}
\hline & $\begin{array}{c}\text { ASEAN-China } \\
\text { ATA (Parent } \\
\text { Agreement) }\end{array}$ & $\begin{array}{c}\text { Protocol 1: Third \& } \\
\text { Fourth freedom } \\
\text { between all cities }\end{array}$ & $\begin{array}{c}\text { Protocol 2: Fifth } \\
\text { Freedom between } \\
\text { selected cities }\end{array}$ \\
\hline \hline Brunei & {$[$ X ] } & [ X ] \\
Cambodia & {$[$ X ] } & Pending adoption \\
Indonesia & {$[$ X ] } & {$[$ X ] } & \\
Lao PDR & {$[$ X ] } & [ X ] & \\
Malaysia & $\checkmark$ & $\checkmark$ & \\
Myanmar & $\checkmark$ & $\checkmark$ & \\
Philippines & {$[$ X ] } & $\checkmark$ X ] & \\
Singapore & $\checkmark$ & $\checkmark$ & \\
Thailand & $\checkmark$ & $\checkmark$ & \\
Vietnam & $\checkmark$ & $\checkmark$ & \\
China & $\checkmark$ & $\checkmark$ & \\
\hline Source: ASEAN & $\checkmark c$ &
\end{tabular}

Source: ASEAN Secretariat. $\checkmark$ denotes state party, [ X ] denotes non-state party

As Table 5 above shows, the ASEAN-China ATA is today already in force among China, Singapore, Malaysia, Thailand, Myanmar and Vietnam. The remaining five ASEAN countries have the option to accept the ATA whenever they feel ready. The near-term advantage for the ASEAN airlines is significant. They now have unlimited penetration into all of China, with the exception of the three excluded points. The Singapore, Malaysian and Thai carriers, in particular, have lost no time in launching flights to new Chinese destinations in recent months. Examples include Silkair (Wuhan, Changsha), Scoot (Tianjin, Shenyang, Qingdao), Thai AirAsia (Wuhan) and AirAsia (Beijing, Kunming, Nanning and most recently, AirAsia X to Shanghai Pudong). The only limitation now relates to slot restrictions, prevalent at major airports such as Beijing Capital.

However, the reality is that there will be long-term systemic disadvantages for the ASEAN carriers. This is because under the ATA's third and fourth freedom regime, these carriers can only operate to the Chinese points from points in their own territory. The Singapore carriers, for instance, can only operate to China from 
Singapore, and not from other points in ASEAN. Similarly, the Malaysian carriers have unlimited access into China, but only from points in Malaysia. To connect China from other ASEAN points outside the airline's home country requires the grant of seventh freedom rights among the ASEAN countries themselves, something they have not yet contemplated. On their part, the Chinese carriers can effectively connect any point in their backyard (which is, after all, a unified market) with any point in the ASEAN countries that accept the ATA and Protocol 1. Hence, if all ten ASEAN countries eventually become state parties, the Chinese airlines will still remain the only carriers that can connect any point in China with any point in ASEAN.

This presents a serious network imbalance: one that stems from the ASEAN countries' own inability or unwillingness to treat themselves as a true single or common market. The dilemma is symptomatic of the broader trading dynamics between any group of smaller states and a larger, unified market. Smaller states will always find themselves disadvantaged in their trading relations with bigger partners unless they forge a unified, common position to balance the other's heft. Politically, this will not be straightforward as it entails individual states placing the region's long-term interest above their own. Within the group of smaller states, there will be "winners" and "losers". However, in the face of bigger challenges from without, there is little other choice but to accept this reality. This is a lesson as familiar in free trade negotiation as it is in open skies talk.

One recalls similar dynamics in the way the European countries were disadvantaged in their multilateral aviation relations with the United States (Tan, 2006). Indeed, that was the reason why the European Commission brought the E.U. member states before the European Court of Justice in the 1990's to compel them to establish a common aviation market. The Commission eventually prevailed, and the result today is that that E.U. airlines can operate from any E.U. point to any U.S. point if they want to. Thus, Air France can fly between London Heathrow and the U.S. if it wishes to (and if it can find slots at Heathrow, a separate matter altogether). Previously, this had been a prohibited "seventh freedom" operation but it is now made possible as the E.U. regards itself as a common market. In other words, all 
flights between the U.S. and the E.U. are now straightforward third/fourth freedom operations for all airlines from both sides.

For ASEAN, the E.U. lesson is wholly relevant and applicable. The member states must similarly band together before they can take on the likes of bigger, unified markets such as China. In fact, India, Japan and Korea are actively looking to establish new agreements with ASEAN similar to the ASEAN-China ATA. Yet, without having forged a true single market in their own backyard first, the ASEAN countries risk disadvantaging their own carriers in the long term, particularly as the Chinese and Indian airlines improve their networks, service standards and competitiveness.

A “true" single market in this regard must thus include seventh freedom rights, that basic market-enlarging feature that would enable the ASEAN carriers to treat the entire region as a common market. The reality, however, is that there is no body or process in ASEAN similar to the European Commission that can compel member states to place the collective regional interest above their own individual interests. For that reason, there is a real risk that the ASEAN airlines will end up seriously disadvantaged against their fast-growing competitors.

Meanwhile, ASEAN and China have concluded talks to adopt a second protocol to their ATA that grants unlimited fifth freedom rights. However, the lack of a united stand among the ASEAN countries and China's own wariness of opening up its major cities have resulted in a deal that is likely to be commercially insignificant. In particular, China's discomfort with an ASEAN carrier (e.g. Singapore Airlines) conducting fifth freedom operations via China to external points (e.g. in the United States or Europe) has led it to exclude the three metropolitan centres of Beijing, Shanghai and Guangzhou from the so-called "external fifth freedom” deal.

Instead, Protocol 2 will include only 10 Chinese cities (largely secondary ones) for the exercise of such fifth freedom rights (see Table 6 below). Even then, there is an upper limit or cap of 14 such weekly flights per country. In turn, the ASEAN countries, apart from Singapore and Brunei, have responded by offering their own secondary points for the deal, subject to the same weekly cap. The small markets between these ASEAN and Chinese secondary points make it highly unlikely that any significant fifth freedom operations will be mounted in the near future. For 
instance, it is doubtful if there will be sufficient traffic for Thai Airways to mount a Chiang Mai - Kunming - Los Angeles operation, or for a Chinese airline to operate Chengdu - Lombok - Sydney.

Similarly, fifth freedom operations are restricted via an ASEAN intermediate point to China or beyond to another ASEAN point. This is the "internal fifth freedom" part of the deal, i.e. ASEAN-ASEAN-China or ASEAN-China-ASEAN operations. Such operations by an ASEAN carrier must begin from the relevant ASEAN secondary city, and may route through another named ASEAN secondary city, to a list of 28 Chinese secondary cities, and may go beyond China to yet another named ASEAN secondary city. Here, China has offered 28 points for the internal deal, beyond the 10 identified for external fifth freedom. There is also no weekly cap. Even then, the list of 28 cities excludes Beijing, Shanghai and Guangzhou, and is essentially an extension of the 10 offered for the external deal. Again, there is probably not enough of a market to justify linking these cities to the ASEAN secondary cities. In short, Protocol 2 is unlikely to be commercially significant, and is reminiscent of the early ASEAN sub-regional arrangements (MAAS Protocols 1 to 4) involving secondary cities only.

Table 6: Points Offered for the ASEAN-China ATA's Protocol 2 on Fifth Freedom Rights

\begin{tabular}{lll}
\hline & $\begin{array}{l}\text { "External” Fifth Freedom } \\
\text { (e.g. ASEAN - China - Third } \\
\text { Country or } \\
\text { China - ASEAN - Third Country) } \\
\text { Example: Malaysian carrier operating } \\
\text { Kota Kinabalu - Kunming - Delhi }\end{array}$ & $\begin{array}{l}\text { "Internal” Fifth Freedom } \\
\text { (e.g. ASEAN - ASEAN - China or } \\
\text { Example: Malaysian carrier operating } \\
\text { Kota Kinabalu - Chiang Mai - } \\
\text { Kunming or } \\
\text { Kota Kinabalu - Haikou - Chiang Mai } \\
\text { [No weekly limit] }\end{array}$ \\
\hline Brunei & Bandar Seri Begawan & \\
Cambodia & Preah Sihanouk (Sihanoukville) & \\
Indonesia & Mataram (Lombok) & \\
Lao PDR & Luang Phabang & \\
Malaysia & Kota Kinabalu & \\
Myanmar & Any point except Yangon & \\
Philippines & Any point except Manila & \\
Singapore & Singapore & \\
\hline
\end{tabular}




\begin{tabular}{|c|c|c|}
\hline Thailand & \multicolumn{2}{|l|}{ Chiang Mai } \\
\hline Vietnam & \multicolumn{2}{|c|}{ Any point except Hanoi and Ho Chi Minh City } \\
\hline \multirow[t]{29}{*}{ China } & Nanning & Nanning \\
\hline & Guilin & Guilin \\
\hline & Kunming & Kunming \\
\hline & Chengdu & Chengdu \\
\hline & Chongqing & Chongqing \\
\hline & Urumqi & Urumqi \\
\hline & Xian & Xian \\
\hline & Changsha & Changsha \\
\hline & Zhengzhou & Zhengzhou \\
\hline & Either Xiamen or Fuzhou & Xiamen \\
\hline & (Total: 10) & Fuzhou \\
\hline & & Xishuangbanna \\
\hline & & Wuhan \\
\hline & & Shenyang \\
\hline & & Dalian \\
\hline & & Haikou \\
\hline & & Sanya \\
\hline & & Guiyang \\
\hline & & Lanzhou \\
\hline & & Xining \\
\hline & & Yinchuan \\
\hline & & Lhasa \\
\hline & & Kashgar \\
\hline & & Hohhot \\
\hline & & Harbin \\
\hline & & Changchun \\
\hline & & Ningbo \\
\hline & & Yanji \\
\hline & & (Total: 28) \\
\hline
\end{tabular}




\section{Air Freight (Cargo) Services}

Some mention must be made of the separate but related regime relating to air freight services. As noted above, the early ASEAN documents such as RIATS had also laid down deadlines for liberalizing the air freight sector. This is considered an equally critical component of the regional economic integration effort, given the export-oriented nature of ASEAN economies. As in other parts of the world, liberalizing the provision of air freight services is considerably less controversial than air passenger services. For one thing, governments tend to care less about how their exports arrive at destinations, as long as the cargo is transported efficiently and at reasonable cost. At the same time, there is much less sentimental attachment (and thus, public awareness and pride) associated with the transport of cargo. Typically, air freight services can also be conducted during off-peak hours (indeed, usually at night), thereby relieving airport and slot congestion problems. For these reasons, states tend to be less reluctant when granting third, fourth, fifth and even seventh freedom rights to foreign carriers' cargo operations.

Within ASEAN, the RIATS commitments as regards air freight services have been formalized in an agreement called the Multilateral Agreement on Full Liberalization of Air Freight Services (MAFLAFS). Adopted in 2009 alongside MAAS and MAFLPAS for passenger services, the MAFLAFS has two Implementing Protocols:

Protocol 1 - Unlimited Third, Fourth and Fifth Freedom Traffic Rights Among Designated Points in ASEAN

Protocol 2 - Unlimited Third, Fourth and Fifth Freedom Traffic Rights Among All Points With International Airports in ASEAN

Protocol 1 provides for unlimited third, fourth and fifth freedom all-cargo traffic rights between points designated by ASEAN member states. Protocol 2 frees up similar rights for all points in ASEAN with international airports. Consistent with the less controversial nature of air cargo transport, the MAFLAFS grants unlimited fifth freedom rights along with third and fourth freedom rights. This contemplates the reality of air freight services - cargo flights typically operate from Points A to B, 
and onwards to $\mathrm{C}, \mathrm{D}, \mathrm{E}$ and so on, without strict requirements on returning to the carrier's home states (unlike passenger flights). At all points along the route, there are typically minimal or no restrictions on the right to discharge and pick up cargo.

Tables 7 and 8 below outline the relevant designated points as well as the ratification status of MAFLAFS and its two Protocols. It can be seen that with the exception of Indonesia, all the member states have ratified and accepted MAFLAFS and its Protocols.

Table 7: MAFLAFS Protocols 1 and 2 and Designated Points

\begin{tabular}{|c|c|c|}
\hline Member States & $\begin{array}{l}\text { Protocol 1: } \\
\text { Third, Fourth } \quad \text { \& } \quad \text { Fifth } \\
\text { Freedom } \\
\text { Points }\end{array}$ & $\begin{array}{l}\text { Protocol 2: } \\
\text { Third, Fourth \& Fifth Freedom } \\
\text { Between All International Points within } \\
\text { ASEAN }\end{array}$ \\
\hline Brunei & Bandar Seri Begawan & \\
\hline Cambodia & Phnom Penh & \\
\hline \multirow[t]{7}{*}{ Indonesia } & Batam & \\
\hline & Balikpapan & \\
\hline & Biak & \\
\hline & Makassar & \\
\hline & Manado & \\
\hline & Palembang & \\
\hline & Pontianak & \\
\hline \multirow[t]{3}{*}{ Lao PDR } & Vientiane & \\
\hline & Luang Phabang & \\
\hline & Pakse & \\
\hline Malaysia & Kuala Lumpur & \\
\hline \multirow[t]{2}{*}{ Myanmar } & Yangon & \\
\hline & Mandalay & \\
\hline \multirow[t]{6}{*}{ Philippines } & Clark & \\
\hline & Subic & \\
\hline & Cebu & All Points with International Airports \\
\hline & Davao & \\
\hline & Iloilo & \\
\hline & Laoag & \\
\hline Singapore & Singapore & \\
\hline \multirow[t]{2}{*}{ Thailand } & Bangkok & \\
\hline & Chiang Mai & \\
\hline
\end{tabular}




\begin{tabular}{ll}
\hline & Hat Yai \\
Khon Kaen & Phuket \\
& U-Tapao \\
& Ubon Ratchathani \\
Vietnam & Ha Noi (Hanoi) \\
& Da Nang \\
& Ho Chi Minh City \\
& Chu Lai \\
\hline
\end{tabular}

Source: MAFLAFS Implementing Protocols 1 and 2

Table 8: Ratification Status of 2009 Multilateral Agreement on Full Liberalization of Air Freight Services (MAFLAFS)

\begin{tabular}{|c|c|c|c|}
\hline & $\begin{array}{l}\text { MAFLAFS } \\
\text { (Parent } \\
\text { Agreement) }\end{array}$ & $\begin{array}{l}\text { Protocol 1: Third, Fourth } \\
\text { \& Fifth Freedom Between } \\
\text { Designated Points }\end{array}$ & $\begin{array}{l}\text { Protocol 2: Third, Fourth \& } \\
\text { Fifth Freedom Between All } \\
\text { International Points within } \\
\text { ASEAN }\end{array}$ \\
\hline Brunei & $\checkmark$ & $\checkmark$ & $\bar{\checkmark}$ \\
\hline Cambodia & $\checkmark$ & $\checkmark$ & $\checkmark$ \\
\hline Indonesia & [X] & [ X ] & {$[\mathrm{X}]$} \\
\hline Lao PDR & $\checkmark$ & $\checkmark$ & $\checkmark$ \\
\hline Malaysia & $\checkmark$ & $\checkmark$ & $\checkmark$ \\
\hline Myanmar & $\checkmark$ & $\checkmark$ & $\checkmark$ \\
\hline Philippines & $\checkmark$ & $\checkmark$ & $\checkmark$ \\
\hline Singapore & $\checkmark$ & $\checkmark$ & $\checkmark$ \\
\hline Thailand & $\checkmark$ & $\checkmark$ & $\checkmark$ \\
\hline Vietnam & $\checkmark$ & $\checkmark$ & $\checkmark$ \\
\hline
\end{tabular}

Source: ASEAN Secretariat. $\checkmark$ denotes state party, [ X ] denotes non-state party.

While foreign carriers' air freight operations are generally less sensitive for states than passenger services, it does not mean that all states readily grant unlimited market access for foreign carriers. As with air passenger transport, the nature and dynamics of airline competition are hugely relevant. It must be noted that MAFLAFS and its Protocols apply to all-cargo transportation only, i.e. carriage on dedicated cargo aircraft or freighters. At the same time, the third, fourth and fifth 
freedom rights apply to carriage wholly within ASEAN only, and not to points outside the region or to domestic carriage within a member state.

In ASEAN, there are only several all-cargo carriers that operate dedicated freighters. These include the cargo arms of Singapore Airlines, Malaysia Airlines and Thai Airways, as well as specialized cargo carriers that can be found in most member states. Both these types of all-cargo operators provide competition to the regular airlines that carry cargo in the holds of their passenger aircraft (the so-called "combination carriers"). The fact that Indonesia is staying out of the MAFLAFS regime is again due to its carriers' concerns that the extensive all-cargo operations of neighbouring countries' carriers affect their own cargo business. These Indonesian carriers include the regular airlines like Garuda (operating combination carriers) as well as specialized cargo airlines such as Cardigair that operate freighters.

\section{Conclusion}

Despite all the problems and shortcomings faced, ASEAN's hope is that member states will in time recognize that it is in their collective interest to forge a truly single aviation market and a common position for negotiating air services with other countries. This would be entirely in line with the broader ambition to achieve an ASEAN Economic Community. However, even the most optimistic observer will concede that time is not on ASEAN's side. In particular, the ASAM's 2015 deadline seems overly ambitious.

The reality is that progress toward a meaningful ASAM is certain to be slow, with big players like Indonesia continuing to hold out on relatively modest issues like third and fourth freedom passenger rights and even air freight services. The huge disparity in airline sizes and competitiveness within the region is a stark reality, as is the pervasive suspicion toward successful airlines from smaller countries such as Singapore and Malaysia. Such dynamics breed the instinct for protectionism amidst a “winners vs. losers” paradigm, even as challenges loom in the form of competition from outside the region. In such a climate, further liberalization (for seventh 
freedom, domestic operations and ownership and control rules) seems even more distant.

Overall, the prospect for a truly single aviation market in ASEAN remains elusive. In the meantime, there are several factors that may hopefully provide the momentum for change beyond 2015 and that might strengthen aviation's contribution toward the ASEAN Economic Community. First is the growing confidence of Indonesian carriers such as Garuda and Lion Air. As these airlines expand their services and increase their competitiveness and appeal to passengers, there may come a time when they feel more secure and see less of a need to resist greater liberalization. In particular, they may themselves come up against limited rights that constrain their expansion overseas. This was what happened recently when Indonesian carriers wishing to expand operations to Singapore came up against their government's own finite limits, leading to a re-negotiation of bilateral capacity. In time, Indonesia may find that keeping to limits may no longer make economic sense, and that an unlimited "open skies" regime would be more beneficial for its overall economy.

Second, there is the pressure created by the provincial governments, tourism authorities and business community to allow greater direct access into regional cities. This may help increase the momentum for more relaxations, particularly if the central government can be convinced that there are bigger benefits for the overall economy with greater liberalization. This has already been seen in the Philippines, and to a lesser extent, in Indonesia. In time, the Indonesian government may come around to recognizing that the national interest of the country is more than the sum of its airlines' narrow interests, and that there are greater benefits for the provinces and the other sectors of the economy that may outweigh the interests of its airlines.

Third, as identified above, there is the pressure created by the agreements with larger countries outside the region such as China. There will conceivably be a "tipping point" when the ASEAN member states realize that the collective regional interest would become compromised by their failure to forge a united stand against external trading partners. The mid- to long-term imbalance affecting their own airlines' competitiveness may well force the ASEAN states to jumpstart the sputtering intra-ASEAN liberalization process. 
Fourth, industry response is critical and should not be under-estimated. The region has now seen how most governments are not yet prepared to dismantle the restrictions in place among themselves in order to meet the competitive challenges posed by external forces. Yet, innovative airline executives have lost no time in crafting imaginative responses that seek to short-circuit or get around the state restrictions, including those that are cast in the bilateral and multilateral agreements. One example is how AirAsia pioneered the cross-border joint venture/subsidiary model - while still imperfect, it allows the airline to get around the "seventh freedom" prohibition and to operate region-wide from multiple hubs using a common, well-recognized brand. In this way, AirAsia has come as close as it can presently get to being an ASEAN “community carrier”.

In conclusion, it is clear that just as cross-border ventures have helped circumvent ownership and control limits, market forces will inevitably force changes as new national and pan-Asian airlines seek to expand their markets. The reality is that liberalization in the marketplace is already happening and pressing forward relentlessly - at times because of, but at other times, in spite of, governments and the agreements they adopt. It is high time that the governments sit up and take notice.

\section{References}

Association of Southeast Asian Nations (ASEAN) (2004), 'Action Plan for ASEAN Air Transport Integration and Liberalization’, ASEAN Document Series 2004, pp.221-226.

CAPA Consulting (2008), Developing ASEAN's Single Aviation Market and Regional Air Services Arrangements with Dialogue Partners. Sydney: CAPA.

Findlay, C., and P. Forsyth (1992), 'Air Transport in the Asian Pacific Region', Asia Pacific Economic Literature 6, pp.1-10.

Forsyth, P., J. King,C. Rodolfo (2006), 'Open Skies in ASEAN', Journal of Air Transport Management 12, pp.143-152.

Indonesia Infrastructure Initiative (IndII) (2012), National Strategy for the Implementation of ASEAN Open Sky Policy Stage 2. Available at: http://www.indii.co.id/publications-detail.php?id_news=240 
Tan, A. K.-J. (2006), 'Liberalizing Aviation in the Asia-Pacific Region: The Impact of the EU Horizontal Mandate', Air and Space Law 31, pp.432-454.

Tan, A. K.-J. (2009), 'Prospects for a Single Aviation Market in Southeast Asia', Annals of Air and Space Law 34, pp.253-283. 


\section{ERIA Discussion Paper Series}

\begin{tabular}{|c|c|c|c|}
\hline No. & Author(s) & Title & Year \\
\hline $2013-22$ & Alan Khee-Jin TAN & $\begin{array}{l}\text { Toward a Single Aviation Market in ASEAN: } \\
\text { Regulatory Reform and Industry Challenges }\end{array}$ & $\begin{array}{l}\text { Oct } \\
2013\end{array}$ \\
\hline $2013-21$ & $\begin{array}{l}\text { Hisanobu SHISHIDO, } \\
\text { Shintaro SUGIYAMA, } \\
\text { Fauziah ZEN }\end{array}$ & $\begin{array}{l}\text { Moving MPAC Forward: Strengthening } \\
\text { Public-Private Partnership, Improving Project } \\
\text { Portfolio and in Search of Practical Financing } \\
\text { Schemes }\end{array}$ & $\begin{array}{l}\text { Oct } \\
2013\end{array}$ \\
\hline $2013-20$ & $\begin{array}{l}\text { Barry DESKER, Mely } \\
\text { CABALLERO-ANTH } \\
\text { ONY, Paul TENG }\end{array}$ & $\begin{array}{l}\text { Thought/Issues Paper on ASEAN Food Security: } \\
\text { Towards a more Comprehensive Framework }\end{array}$ & $\begin{array}{l}\text { Oct } \\
2013\end{array}$ \\
\hline 2013-19 & $\begin{array}{l}\text { Toshihiro KUDO, } \\
\text { Satoru KUMAGAI, So } \\
\text { UMEZAKI }\end{array}$ & $\begin{array}{l}\text { Making Myanmar the Star Growth Performer in } \\
\text { ASEAN in the Next Decade: A Proposal of Five } \\
\text { Growth Strategies }\end{array}$ & $\begin{array}{l}\text { Sep } \\
2013\end{array}$ \\
\hline $2013-18$ & Ruperto MAJUCA & $\begin{array}{l}\text { Managing Economic Shocks and } \\
\text { Macroeconomic Coordination in an Integrated } \\
\text { Region: ASEAN Beyond } 2015\end{array}$ & $\begin{array}{l}\text { Sep } \\
2013\end{array}$ \\
\hline $2013-17$ & $\begin{array}{l}\text { Cassy LEE and Yoshifumi } \\
\text { FUKUNAGA }\end{array}$ & $\begin{array}{l}\text { Competition Policy Challenges of Single Market } \\
\text { and Production Base }\end{array}$ & $\begin{array}{l}\text { Sep } \\
2013\end{array}$ \\
\hline 2013-16 & Simon TAY & $\begin{array}{l}\text { Growing an ASEAN Voice? : A Common } \\
\text { Platform in Global and Regional Governance }\end{array}$ & $\begin{array}{l}\text { Sep } \\
2013\end{array}$ \\
\hline $2013-15$ & $\begin{array}{l}\text { Danilo C. ISRAEL and } \\
\text { Roehlano M. BRIONES }\end{array}$ & $\begin{array}{l}\text { Impacts of Natural Disasters on Agriculture, Food } \\
\text { Security, and Natural Resources and Environment in } \\
\text { the Philippines }\end{array}$ & $\begin{array}{l}\text { Aug } \\
2013\end{array}$ \\
\hline 2013-14 & $\begin{array}{l}\text { Allen Yu-Hung LAI and } \\
\text { Seck L. TAN }\end{array}$ & $\begin{array}{l}\text { Impact of Disasters and Disaster Risk Management in } \\
\text { Singapore: A Case Study of Singapore's Experience } \\
\text { in Fighting the SARS Epidemic }\end{array}$ & $\begin{array}{l}\text { Aug } \\
2013\end{array}$ \\
\hline 2013-13 & Brent LAYTON & $\begin{array}{l}\text { Impact of Natural Disasters on Production Networks } \\
\text { and Urbanization in New Zealand }\end{array}$ & $\begin{array}{l}\text { Aug } \\
2013\end{array}$ \\
\hline 2013-12 & Mitsuyo ANDO & $\begin{array}{l}\text { Impact of Recent Crises and Disasters on Regional } \\
\text { Production/Distribution Networks and Trade in Japan }\end{array}$ & $\begin{array}{l}\text { Aug } \\
2013\end{array}$ \\
\hline 2013-11 & Le Dang TRUNG & $\begin{array}{l}\text { Economic and Welfare Impacts of Disasters in East } \\
\text { Asia and Policy Responses: The Case of Vietnam }\end{array}$ & $\begin{array}{l}\text { Aug } \\
2013\end{array}$ \\
\hline 2013-10 & Sann VATHANA, Sothea & Impact of Disasters and Role of Social Protection in & Aug \\
\hline
\end{tabular}




\begin{tabular}{|c|c|c|c|}
\hline No. & Author(s) & Title & Year \\
\hline & $\begin{array}{l}\text { OUM, Ponhrith KAN, } \\
\text { Colas CHERVIER }\end{array}$ & Natural Disaster Risk Management in Cambodia & 2013 \\
\hline 2013-09 & $\begin{array}{l}\text { Sommarat CHANTARAT, } \\
\text { Krirk PANNANGPETCH, } \\
\text { Nattapong } \\
\text { PUTTANAPONG, Preesan } \\
\text { RAKWATIN, and Thanasin } \\
\text { TANOMPONGPHANDH }\end{array}$ & $\begin{array}{l}\text { Index-Based Risk Financing and Development of } \\
\text { Natural Disaster Insurance Programs in Developing } \\
\text { Asian Countries }\end{array}$ & $\begin{array}{l}\text { Aug } \\
2013\end{array}$ \\
\hline 2013-08 & $\begin{array}{l}\text { Ikumo ISONO and Satoru } \\
\text { KUMAGAI }\end{array}$ & $\begin{array}{l}\text { Long-run Economic Impacts of Thai Flooding: } \\
\text { Geographical Simulation Analysis }\end{array}$ & $\begin{array}{l}\text { July } \\
2013\end{array}$ \\
\hline 2013-07 & $\begin{array}{l}\text { Yoshifumi FUKUNAGA } \\
\text { and Hikaru ISHIDO }\end{array}$ & $\begin{array}{l}\text { Assessing the Progress of Services Liberalization in } \\
\text { the ASEAN-China Free Trade Area (ACFTA) }\end{array}$ & $\begin{array}{l}\text { May } \\
2013\end{array}$ \\
\hline 2013-06 & $\begin{array}{l}\text { Ken ITAKURA, Yoshifumi } \\
\text { FUKUNAGA, and Ikumo } \\
\text { ISONO }\end{array}$ & $\begin{array}{l}\text { A CGE Study of Economic Impact of Accession of } \\
\text { Hong Kong to ASEAN-China Free Trade Agreement }\end{array}$ & $\begin{array}{l}\text { May } \\
2013\end{array}$ \\
\hline $2013-05$ & $\begin{array}{l}\text { Misa OKABE and Shujiro } \\
\text { URATA }\end{array}$ & The Impact of AFTA on Intra-AFTA Trade & $\begin{array}{l}\text { May } \\
2013\end{array}$ \\
\hline 2013-04 & Kohei SHIINO & $\begin{array}{l}\text { How Far Will Hong Kong's Accession to ACFTA will } \\
\text { Impact on Trade in Goods? }\end{array}$ & $\begin{array}{l}\text { May } \\
2013\end{array}$ \\
\hline 2013-03 & $\begin{array}{l}\text { Cassey LEE and Yoshifumi } \\
\text { FUKUNAGA }\end{array}$ & $\begin{array}{l}\text { ASEAN Regional Cooperation on Competition } \\
\text { Policy }\end{array}$ & $\begin{array}{l}\text { Apr } \\
2013\end{array}$ \\
\hline 2013-02 & $\begin{array}{l}\text { Yoshifumi FUKUNAGA } \\
\text { and Ikumo ISONO }\end{array}$ & $\begin{array}{l}\text { Taking ASEAN+1 FTAs towards the RCEP: } \\
\text { A Mapping Study }\end{array}$ & $\begin{array}{l}\text { Jan } \\
2013\end{array}$ \\
\hline 2013-01 & Ken ITAKURA & $\begin{array}{l}\text { Impact of Liberalization and Improved Connectivity } \\
\text { and Facilitation in ASEAN for the ASEAN Economic } \\
\text { Community }\end{array}$ & $\begin{array}{l}\text { Jan } \\
2013\end{array}$ \\
\hline $2012-17$ & $\begin{array}{l}\text { Sun XUEGONG, Guo } \\
\text { LIYAN, Zeng ZHENG }\end{array}$ & $\begin{array}{l}\text { Market Entry Barriers for FDI and Private Investors: } \\
\text { Lessons from China's Electricity Market }\end{array}$ & $\begin{array}{l}\text { Aug } \\
2012\end{array}$ \\
\hline $2012-16$ & Yanrui WU & $\begin{array}{l}\text { Electricity Market Integration: Global Trends and } \\
\text { Implications for the EAS Region }\end{array}$ & $\begin{array}{l}\text { Aug } \\
2012\end{array}$ \\
\hline $2012-15$ & $\begin{array}{l}\text { Youngho CHANG, Yanfei } \\
\text { LI }\end{array}$ & $\begin{array}{l}\text { Power Generation and Cross-border Grid Planning for } \\
\text { the Integrated ASEAN Electricity Market: A Dynamic } \\
\text { Linear Programming Model }\end{array}$ & $\begin{array}{l}\text { Aug } \\
2012\end{array}$ \\
\hline $2012-14$ & Yanrui WU, Xunpeng SHI & Economic Development, Energy Market Integration and & Aug \\
\hline
\end{tabular}




\begin{tabular}{|c|c|c|c|}
\hline No. & Author(s) & Title & Year \\
\hline & & Energy Demand: Implications for East Asia & 2012 \\
\hline $2012-13$ & $\begin{array}{l}\text { Joshua AIZENMAN, } \\
\text { Minsoo LEE, and } \\
\text { Donghyun PARK }\end{array}$ & $\begin{array}{l}\text { The Relationship between Structural Change and } \\
\text { Inequality: A Conceptual Overview with Special } \\
\text { Reference to Developing Asia }\end{array}$ & $\begin{array}{l}\text { July } \\
2012\end{array}$ \\
\hline $2012-12$ & $\begin{array}{l}\text { Hyun-Hoon LEE, Minsoo } \\
\text { LEE, and Donghyun PARK }\end{array}$ & $\begin{array}{l}\text { Growth Policy and Inequality in Developing Asia: } \\
\text { Lessons from Korea }\end{array}$ & $\begin{array}{l}\text { July } \\
2012\end{array}$ \\
\hline $2012-11$ & Cassey LEE & $\begin{array}{l}\text { Knowledge Flows, Organization and Innovation: } \\
\text { Firm-Level Evidence from Malaysia }\end{array}$ & $\begin{array}{l}\text { June } \\
2012\end{array}$ \\
\hline $2012-10$ & $\begin{array}{l}\text { Jacques MAIRESSE, Pierre } \\
\text { MOHNEN, Yayun ZHAO, } \\
\text { and Feng ZHEN }\end{array}$ & $\begin{array}{l}\text { Globalization, Innovation and Productivity in } \\
\text { Manufacturing Firms: A Study of Four Sectors of China }\end{array}$ & $\begin{array}{l}\text { June } \\
2012\end{array}$ \\
\hline 2012-09 & Ari KUNCORO & $\begin{array}{l}\text { Globalization and Innovation in Indonesia: Evidence } \\
\text { from Micro-Data on Medium and Large Manufacturing } \\
\text { Establishments }\end{array}$ & $\begin{array}{l}\text { June } \\
2012\end{array}$ \\
\hline 2012-08 & Alfons PALANGKARAYA & $\begin{array}{l}\text { The Link between Innovation and Export: Evidence } \\
\text { from Australia's Small and Medium Enterprises }\end{array}$ & $\begin{array}{l}\text { June } \\
2012\end{array}$ \\
\hline $2012-07$ & $\begin{array}{l}\text { Chin Hee HAHN and } \\
\text { Chang-Gyun PARK }\end{array}$ & $\begin{array}{l}\text { Direction of Causality in Innovation-Exporting Linkage: } \\
\text { Evidence on Korean Manufacturing }\end{array}$ & $\begin{array}{l}\text { June } \\
2012\end{array}$ \\
\hline 2012-06 & Keiko ITO & $\begin{array}{l}\text { Source of Learning-by-Exporting Effects: Does } \\
\text { Exporting Promote Innovation? }\end{array}$ & $\begin{array}{l}\text { June } \\
2012\end{array}$ \\
\hline $2012-05$ & Rafaelita M. ALDABA & $\begin{array}{l}\text { Trade Reforms, Competition, and Innovation in the } \\
\text { Philippines }\end{array}$ & $\begin{array}{l}\text { June } \\
2012\end{array}$ \\
\hline $2012-04$ & $\begin{array}{l}\text { Toshiyuki MATSUURA } \\
\text { and Kazunobu } \\
\text { HAYAKAWA }\end{array}$ & $\begin{array}{l}\text { The Role of Trade Costs in FDI Strategy of } \\
\text { Heterogeneous Firms: Evidence from Japanese } \\
\text { Firm-level Data }\end{array}$ & $\begin{array}{l}\text { June } \\
2012\end{array}$ \\
\hline $2012-03$ & $\begin{array}{l}\text { Kazunobu HAYAKAWA, } \\
\text { Fukunari KIMURA, and } \\
\text { Hyun-Hoon LEE }\end{array}$ & $\begin{array}{l}\text { How Does Country Risk Matter for Foreign Direct } \\
\text { Investment? }\end{array}$ & $\begin{array}{l}\text { Feb } \\
2012\end{array}$ \\
\hline $2012-02$ & $\begin{array}{l}\text { Ikumo ISONO, Satoru } \\
\text { KUMAGAI, Fukunari } \\
\text { KIMURA }\end{array}$ & $\begin{array}{l}\text { Agglomeration and Dispersion in China and ASEAN: } \\
\text { A Geographical Simulation Analysis }\end{array}$ & $\begin{array}{l}\text { Jan } \\
2012\end{array}$ \\
\hline $2012-01$ & $\begin{array}{l}\text { Mitsuyo ANDO and } \\
\text { Fukunari KIMURA }\end{array}$ & $\begin{array}{l}\text { How Did the Japanese Exports Respond to Two Crises } \\
\text { in the International Production Network?: The Global }\end{array}$ & $\begin{array}{l}\text { Jan } \\
2012\end{array}$ \\
\hline
\end{tabular}




\begin{tabular}{|c|c|c|c|}
\hline No. & Author(s) & Title & Year \\
\hline & & Financial Crisis and the East Japan Earthquake & \\
\hline $2011-10$ & $\begin{array}{l}\text { Tomohiro MACHIKITA } \\
\text { and Yasushi UEKI }\end{array}$ & $\begin{array}{l}\text { Interactive Learning-driven Innovation in } \\
\text { Upstream-Downstream Relations: Evidence from } \\
\text { Mutual Exchanges of Engineers in Developing } \\
\text { Economies }\end{array}$ & $\begin{array}{l}\text { Dec } \\
2011\end{array}$ \\
\hline 2011-09 & $\begin{array}{l}\text { Joseph D. ALBA, Wai-Mun } \\
\text { CHIA, and Donghyun } \\
\text { PARK }\end{array}$ & $\begin{array}{l}\text { Foreign Output Shocks and Monetary Policy Regimes } \\
\text { in Small Open Economies: A DSGE Evaluation of East } \\
\text { Asia }\end{array}$ & $\begin{array}{l}\text { Dec } \\
2011\end{array}$ \\
\hline 2011-08 & $\begin{array}{l}\text { Tomohiro MACHIKITA } \\
\text { and Yasushi UEKI }\end{array}$ & $\begin{array}{l}\text { Impacts of Incoming Knowledge on Product Innovation: } \\
\text { Econometric Case Studies of Technology Transfer of } \\
\text { Auto-related Industries in Developing Economies }\end{array}$ & $\begin{array}{l}\text { Nov } \\
2011\end{array}$ \\
\hline 2011-07 & Yanrui WU & $\begin{array}{l}\text { Gas Market Integration: Global Trends and Implications } \\
\text { for the EAS Region }\end{array}$ & $\begin{array}{l}\text { Nov } \\
2011\end{array}$ \\
\hline 2011-06 & Philip Andrews-SPEED & $\begin{array}{l}\text { Energy Market Integration in East Asia: A Regional } \\
\text { Public Goods Approach }\end{array}$ & $\begin{array}{l}\text { Nov } \\
2011\end{array}$ \\
\hline $2011-05$ & $\begin{array}{l}\text { Yu SHENG, } \\
\text { Xunpeng SHI }\end{array}$ & $\begin{array}{l}\text { Energy Market Integration and Economic } \\
\text { Convergence: Implications for East Asia }\end{array}$ & $\begin{array}{l}\text { Oct } \\
2011\end{array}$ \\
\hline 2011-04 & $\begin{array}{l}\text { Sang-Hyop LEE, Andrew } \\
\text { MASON, and Donghyun } \\
\text { PARK }\end{array}$ & $\begin{array}{l}\text { Why Does Population Aging Matter So Much for } \\
\text { Asia? Population Aging, Economic Security and } \\
\text { Economic Growth in Asia }\end{array}$ & $\begin{array}{l}\text { Aug } \\
2011\end{array}$ \\
\hline $2011-03$ & $\begin{array}{l}\text { Xunpeng SHI, } \\
\text { Shinichi GOTO }\end{array}$ & $\begin{array}{l}\text { Harmonizing Biodiesel Fuel Standards in East Asia: } \\
\text { Current Status, Challenges and the Way Forward }\end{array}$ & $\begin{array}{l}\text { May } \\
2011\end{array}$ \\
\hline 2011-02 & Hikari ISHIDO & $\begin{array}{l}\text { Liberalization of Trade in Services under ASEAN }+n \text { : } \\
\text { A Mapping Exercise }\end{array}$ & $\begin{array}{l}\text { May } \\
2011\end{array}$ \\
\hline 2011-01 & $\begin{array}{l}\text { Kuo-I CHANG, Kazunobu } \\
\text { HAYAKAWA } \\
\text { Toshiyuki MATSUURA }\end{array}$ & $\begin{array}{l}\text { Location Choice of Multinational Enterprises in } \\
\text { China: Comparison between Japan and Taiwan }\end{array}$ & $\begin{array}{l}\text { Mar } \\
2011\end{array}$ \\
\hline $2010-11$ & $\begin{array}{l}\text { Charles HARVIE, } \\
\text { Dionisius NARJOKO, } \\
\text { Sothea OUM }\end{array}$ & $\begin{array}{l}\text { Firm Characteristic Determinants of SME } \\
\text { Participation in Production Networks }\end{array}$ & $\begin{array}{l}\text { Oct } \\
2010\end{array}$ \\
\hline $2010-10$ & Mitsuyo ANDO & $\begin{array}{l}\text { Machinery Trade in East Asia, and the Global } \\
\text { Financial Crisis }\end{array}$ & $\begin{array}{l}\text { Oct } \\
2010\end{array}$ \\
\hline 2010-09 & $\begin{array}{l}\text { Fukunari KIMURA } \\
\text { Ayako OBASHI }\end{array}$ & $\begin{array}{l}\text { International Production Networks in Machinery } \\
\text { Industries: Structure and Its Evolution }\end{array}$ & $\begin{array}{l}\text { Sep } \\
2010\end{array}$ \\
\hline
\end{tabular}




\begin{tabular}{|c|c|c|c|}
\hline No. & Author(s) & Title & Year \\
\hline $2010-08$ & $\begin{array}{l}\text { Tomohiro MACHIKITA, } \\
\text { Shoichi MIYAHARA, } \\
\text { Masatsugu TSUJI, and } \\
\text { Yasushi UEKI }\end{array}$ & $\begin{array}{l}\text { Detecting Effective Knowledge Sources in Product } \\
\text { Innovation: Evidence from Local Firms and } \\
\text { MNCs/JVs in Southeast Asia }\end{array}$ & $\begin{array}{l}\text { Aug } \\
2010\end{array}$ \\
\hline $2010-07$ & $\begin{array}{l}\text { Tomohiro MACHIKITA, } \\
\text { Masatsugu TSUJI, and } \\
\text { Yasushi UEKI }\end{array}$ & $\begin{array}{l}\text { How ICTs Raise Manufacturing Performance: } \\
\text { Firm-level Evidence in Southeast Asia }\end{array}$ & $\begin{array}{l}\text { Aug } \\
2010\end{array}$ \\
\hline $2010-06$ & Xunpeng SHI & $\begin{array}{l}\text { Carbon Footprint Labeling Activities in the East Asia } \\
\text { Summit Region: Spillover Effects to Less Developed } \\
\text { Countries }\end{array}$ & $\begin{array}{l}\text { July } \\
2010\end{array}$ \\
\hline $2010-05$ & $\begin{array}{l}\text { Kazunobu HAYAKAWA, } \\
\text { Fukunari KIMURA, and } \\
\text { Tomohiro MACHIKITA }\end{array}$ & $\begin{array}{l}\text { Firm-level Analysis of Globalization: A Survey of the } \\
\text { Eight Literatures }\end{array}$ & $\begin{array}{l}\text { Mar } \\
2010\end{array}$ \\
\hline $2010-04$ & $\begin{array}{l}\text { Tomohiro MACHIKITA } \\
\text { and Yasushi UEKI }\end{array}$ & $\begin{array}{l}\text { The Impacts of Face-to-face and Frequent } \\
\text { Interactions on Innovation: } \\
\text { Upstream-Downstream Relations }\end{array}$ & $\begin{array}{l}\text { Feb } \\
2010\end{array}$ \\
\hline $2010-03$ & $\begin{array}{l}\text { Tomohiro MACHIKITA } \\
\text { and Yasushi UEKI }\end{array}$ & $\begin{array}{l}\text { Innovation in Linked and Non-linked Firms: } \\
\text { Effects of Variety of Linkages in East Asia }\end{array}$ & $\begin{array}{l}\text { Feb } \\
2010\end{array}$ \\
\hline $2010-02$ & $\begin{array}{l}\text { Tomohiro MACHIKITA } \\
\text { and Yasushi UEKI }\end{array}$ & $\begin{array}{l}\text { Search-theoretic Approach to Securing New } \\
\text { Suppliers: Impacts of Geographic Proximity for } \\
\text { Importer and Non-importer }\end{array}$ & $\begin{array}{l}\text { Feb } \\
2010\end{array}$ \\
\hline 2010-01 & $\begin{array}{l}\text { Tomohiro MACHIKITA } \\
\text { and Yasushi UEKI }\end{array}$ & $\begin{array}{l}\text { Spatial Architecture of the Production Networks in } \\
\text { Southeast Asia: } \\
\text { Empirical Evidence from Firm-level Data }\end{array}$ & $\begin{array}{l}\text { Feb } \\
2010\end{array}$ \\
\hline $2009-23$ & Dionisius NARJOKO & $\begin{array}{l}\text { Foreign Presence Spillovers and Firms' Export } \\
\text { Response: } \\
\text { Evidence from the Indonesian Manufacturing }\end{array}$ & $\begin{array}{l}\text { Nov } \\
2009\end{array}$ \\
\hline $2009-22$ & $\begin{array}{l}\text { Kazunobu HAYAKAWA, } \\
\text { Daisuke HIRATSUKA, } \\
\text { Kohei SHIINO, and Seiya } \\
\text { SUKEGAWA }\end{array}$ & Who Uses Free Trade Agreements? & $\begin{array}{l}\text { Nov } \\
2009\end{array}$ \\
\hline $2009-21$ & Ayako OBASHI & $\begin{array}{l}\text { Resiliency of Production Networks in Asia: } \\
\text { Evidence from the Asian Crisis }\end{array}$ & $\begin{array}{l}\text { Oct } \\
2009\end{array}$ \\
\hline
\end{tabular}




\begin{tabular}{|c|c|c|c|}
\hline No. & Author(s) & Title & Year \\
\hline \multirow{2}{*}{$2009-20$} & Mitsuyo ANDO and & \multirow{2}{*}{ Fragmentation in East Asia: Further Evidence } & Oct \\
\hline & Fukunari KIMURA & & 2009 \\
\hline \multirow{2}{*}{ 2009-19 } & \multirow{2}{*}{ Xunpeng SHI } & The Prospects for Coal: Global Experience and & Sept \\
\hline & & Implications for Energy Policy & 2009 \\
\hline \multirow{2}{*}{$2009-18$} & \multirow{2}{*}{ Sothea OUM } & Income Distribution and Poverty in a CGE & Jun \\
\hline & & Framework: A Proposed Methodology & 2009 \\
\hline \multirow{2}{*}{$2009-17$} & \multirow{2}{*}{$\begin{array}{l}\text { Erlinda M. MEDALLA } \\
\text { and Jenny BALBOA }\end{array}$} & ASEAN Rules of Origin: Lessons and & Jun \\
\hline & & Recommendations for the Best Practice & 2009 \\
\hline \multirow{2}{*}{$2009-16$} & \multirow{2}{*}{ Masami ISHIDA } & \multirow{2}{*}{ Special Economic Zones and Economic Corridors } & Jun \\
\hline & & & 2009 \\
\hline \multirow{2}{*}{$2009-15$} & \multirow{2}{*}{ Toshihiro KUDO } & Border Area Development in the GMS: Turning the & May \\
\hline & & Periphery into the Center of Growth & 2009 \\
\hline \multirow{2}{*}{$2009-14$} & Claire HOLLWEG and & Measuring Regulatory Restrictions in Logistics & Apr \\
\hline & Marn-Heong WONG & Services & 2009 \\
\hline \multirow{2}{*}{$2009-13$} & \multirow{2}{*}{ Loreli C. De DIOS } & \multirow{2}{*}{ Business View on Trade Facilitation } & Apr \\
\hline & & & 2009 \\
\hline \multirow{2}{*}{$2009-12$} & Patricia SOURDIN and & \multirow{2}{*}{ Monitoring Trade Costs in Southeast Asia } & Apr \\
\hline & Richard POMFRET & & 2009 \\
\hline \multirow{2}{*}{$2009-11$} & Philippa DEE and & Barriers to Trade in Health and Financial Services in & Apr \\
\hline & Huong DINH & ASEAN & 2009 \\
\hline $2009-10$ & Sayuri SHIRAI & $\begin{array}{l}\text { The Impact of the US Subprime Mortgage Crisis on } \\
\text { the World and East Asia: Through Analyses of } \\
\text { Cross-border Capital Movements }\end{array}$ & $\begin{array}{l}\text { Apr } \\
2009\end{array}$ \\
\hline 2009-09 & $\begin{array}{l}\text { Mitsuyo ANDO and } \\
\text { Akie IRIYAMA }\end{array}$ & $\begin{array}{l}\text { International Production Networks and Export/Import } \\
\text { Responsiveness to Exchange Rates: The Case of } \\
\text { Japanese Manufacturing Firms }\end{array}$ & $\begin{array}{l}\text { Mar } \\
2009\end{array}$ \\
\hline \multirow{2}{*}{ 2009-08 } & \multirow{2}{*}{$\begin{array}{l}\text { Archanun } \\
\text { KOHPAIBOON }\end{array}$} & \multirow{2}{*}{$\begin{array}{l}\text { Vertical and Horizontal FDI Technology } \\
\text { Spillovers:Evidence from Thai Manufacturing }\end{array}$} & Mar \\
\hline & & & 2009 \\
\hline $2009-07$ & $\begin{array}{l}\text { Kazunobu HAYAKAWA, } \\
\text { Fukunari KIMURA, and } \\
\text { Toshiyuki MATSUURA }\end{array}$ & $\begin{array}{l}\text { Gains from Fragmentation at the Firm Level: } \\
\text { Evidence from Japanese Multinationals in East Asia }\end{array}$ & $\begin{array}{l}\text { Mar } \\
2009\end{array}$ \\
\hline 2009-06 & Dionisius A. NARJOKO & $\begin{array}{l}\text { Plant Entry in a More } \\
\text { LiberalisedIndustrialisationProcess: An Experience } \\
\text { of Indonesian Manufacturing during the 1990s }\end{array}$ & $\begin{array}{l}\text { Mar } \\
2009\end{array}$ \\
\hline
\end{tabular}




\begin{tabular}{|c|c|c|c|}
\hline No. & Author(s) & Title & Year \\
\hline 2009-05 & $\begin{array}{l}\text { Kazunobu HAYAKAWA, } \\
\text { Fukunari KIMURA, and } \\
\text { Tomohiro MACHIKITA }\end{array}$ & Firm-level Analysis of Globalization: A Survey & $\begin{array}{l}\text { Mar } \\
2009\end{array}$ \\
\hline 2009-04 & $\begin{array}{l}\text { Chin Hee HAHN and } \\
\text { Chang-Gyun PARK }\end{array}$ & $\begin{array}{l}\text { Learning-by-exporting in Korean Manufacturing: } \\
\text { A Plant-level Analysis }\end{array}$ & $\begin{array}{l}\text { Mar } \\
2009\end{array}$ \\
\hline 2009-03 & Ayako OBASHI & $\begin{array}{l}\text { Stability of Production Networks in East Asia: } \\
\text { Duration and Survival of Trade }\end{array}$ & $\begin{array}{l}\text { Mar } \\
2009\end{array}$ \\
\hline 2009-02 & Fukunari KIMURA & $\begin{array}{l}\text { The Spatial Structure of Production/Distribution } \\
\text { Networks and Its Implication for Technology } \\
\text { Transfers and Spillovers }\end{array}$ & $\begin{array}{l}\text { Mar } \\
2009\end{array}$ \\
\hline 2009-01 & $\begin{array}{l}\text { Fukunari KIMURA and } \\
\text { Ayako OBASHI }\end{array}$ & $\begin{array}{l}\text { International Production Networks: Comparison } \\
\text { between China and ASEAN }\end{array}$ & $\begin{array}{l}\text { Jan } \\
2009\end{array}$ \\
\hline $2008-03$ & $\begin{array}{l}\text { Kazunobu HAYAKAWA } \\
\text { and Fukunari KIMURA }\end{array}$ & $\begin{array}{l}\text { The Effect of Exchange Rate Volatility on } \\
\text { International Trade in East Asia }\end{array}$ & $\begin{array}{l}\text { Dec } \\
2008\end{array}$ \\
\hline 2008-02 & $\begin{array}{l}\text { Satoru KUMAGAI, } \\
\text { Toshitaka GOKAN, } \\
\text { Ikumo ISONO, and } \\
\text { Souknilanh KEOLA }\end{array}$ & $\begin{array}{l}\text { Predicting Long-Term Effects of Infrastructure } \\
\text { Development Projects in Continental South East } \\
\text { Asia: IDE Geographical Simulation Model }\end{array}$ & $\begin{array}{l}\text { Dec } \\
2008\end{array}$ \\
\hline 2008-01 & $\begin{array}{l}\text { Kazunobu HAYAKAWA, } \\
\text { Fukunari KIMURA, and } \\
\text { Tomohiro MACHIKITA }\end{array}$ & Firm-level Analysis of Globalization: A Survey & $\begin{array}{l}\text { Dec } \\
2008\end{array}$ \\
\hline
\end{tabular}

